\title{
$C_{0} \mathbf{I} \cdot \mathbf{R}^{\circ} \mathbf{P} \cdot \mathrm{E}^{\prime} \mathrm{E}$
}

Centre Interuniversitaire sur le Risque, les Politiques Économiques et l'Emploi

Cahier de recherche/Working Paper 13-23

\section{The Role of Polygyny in the Intrahousehold Efficiency of Agricultural Production in West Africa}

Anyck Dauphin

Août/August 2013

Dauphin : Département des sciences sociales, Université du Québec en Outaouais, 283 boulevard Alexandre-Taché, Gatineau (Québec) Canada J8X 3X7. Phone : 819 595-3900

anyck.dauphin@uqo.ca

We wish to thank Christopher Udry for sharing the ICRISAT Farm Level Studies on Burkina Faso as well as Valerie Kelly for making available the IFPRI/ISRA Small Study of Consumption \& Supply Impacts of Agricultural Policies in the Peanut Basin and Senegal Oriental. We also thank IFPRI for freely distributing the Benin Small Farmer Survey, and participants at the 2012 Canadian Development Economics Study Group sessions of the Canadian Economic Association Annual Conference. 


\begin{abstract}
:
Polygyny is an institution with deep roots in West Africa. Many papers have attempted to explain the rationality and persistence of this phenomenon through time. Less effort has been devoted to studying the effect of polygyny on household economic behavior. This question is policy relevant given the pressure underway to eliminate polygyny. This paper provides new empirical evidence on whether polygyny leads to an improvement or a worsening of intra-household efficiency for three countries with high levels of polygyny: Benin, Burkina Faso and Senegal. The e

vidence we obtain is mixed. In Benin, polygyny does not seem to have an impact on intra-household efficiency, while it appears, in the longer run, to improve it in Burkina Faso, but to decrease it in Senegal.
\end{abstract}

Keywords: Polygamy, Efficiency, Agriculture, Africa

JEL Classification: D13, D79, J12, O13, O55 


\section{Introduction}

Polygyny is an institution with deep roots in West Africa. ${ }^{1}$ It is socially accepted in more than half of the countries in this region. ${ }^{2}$ The percentage of men that are polygamists reaches $37 \%$ in Guinea and 35\% in Gambia. Many papers have attempted to explain the determinants and persistence of this phenomenon through time (e.g. Boserup, 1970; Becker, 1974; Grossbard, 1978; Bergstrom, 1994; Jacoby, 1995; Gould et al., 2008). Less effort has been devoted to studying the effects of polygyny on household economic behavior. One noteworthy exception is the paper by Tertilt (2005), which shows that polygyny crowds-out investments in physical assets and increases fertility, suggesting that polygyny is bad for development. Akresh, Chen and More (2012a,b) and Dauphin, Fortin and Lacroix (2011) are the only papers in the economics literature as of now to study whether polygamous households behave efficiently. How polygyny impacts intrahousehold efficiency is policy relevant given the strong pressure put on countries to eliminate polygyny. ${ }^{3}$ Knowledge of the effect of the monogamy versus polygamy status on the efficiency of agricultural decisions in particular is especially important given the crucial role played by agriculture in the livelihood of poor West African households.

Akresh et al. (2012a,b) study the agricultural production of Burkina Faso households and find that inefficiency, while present in polygamous households, is less pronounced than in monogamous ones. They ascribe this to the fact that altruism is lower in polygamous marriages, because wives do not generally care for each other. This, they say, increases the incentive of spouses to cooperate by lowering the utility they expect to receive in a non-cooperative equilibrium. Dauphin et al. (2011), who test the efficiency of consumption decisions of Burkina Faso households, conclude that polygamous households are inefficient. Although they do not test whether monogamous households are less inefficient, they argue that polygamous households should be at least as inefficient as monogamous households, since they face the same potential sources of ineffi-

\footnotetext{
${ }^{1}$ Polygyny is a form of marriage in which a man has several wives at the same time. Polygamy encompasses both polygyny and its reverse, polyandry, in which a woman has more than one husband.

${ }^{2}$ This figure is based on the 2009 OECD Gender Institution and Development database.

${ }^{3}$ Article 16 of the UN Committee for the Elimination of Discrimination Against Women (CEDAW) prohibits polygamy.
} 
ciency, such as difficulties enforcing the marriage contract (Lundberg and Pollak, 1993, 2003; Ligon et al., 2002; Basu, 2006), information asymmetry between the spouses (Bloch and Rao, 2002; Ashraf, 2009), social norms (Udry, 1996; Duflo and Udry, 2004), and jealousy between the wives, which could exacerbate cooperation between the spouses.

Anthropologists have been debating for some time on whether polygyny generates mainly cooperation or conflicts between the wives. A number of them have argued that polygyny induces cooperative behavior between wives like the sharing of maternal and domestic responsibilities (e.g. Steady, 1987; Madhavan, 2002). Others believe that polygyny is mostly conducive to conflicting behaviors, ranging from verbal and physical aggression to poisoning (e.g. Flinn and England, 1995; Jankowiak et al., 2005; Kazianga and Klonner, 2009). Some also find that the tensions it creates within the household adversely impact the physical and mental health of the wives and their children (e.g. Arney, 2002; Hadley, 2005; Al-Krenawi and Graham, 2006).

This paper provides new empirical evidence on whether polygyny leads to an improvement in intrahousehold efficiency. ${ }^{4}$ The causal effect of the marital status on the intrahousehold efficiency of agricultural production is tentatively estimated for three countries where the prevalence of polygyny is high: Benin, Burkina Faso and Senegal. Intrahousehold inefficiency of agricultural production is assessed following Udry (1996) and Akresh et al. (2012a,b). When possible, two different identification strategies are implemented: an approach based on the recent experience of households going through a change in its number of wives and an instrumental variable (IV) approach relying on the relationship between polygyny and ethnicity. Both strategies are used along with a fixed effect approach controlling for unobserved confounders.

We get mixed evidence. In Benin, polygyny does not appear to have an impact on intrahousehold efficiency. We obtain the same result for Burkina Faso and Senegal with the first identification strategy. However, based on the IV approach, polygyny is found to increase intrahousehold efficiency in Burkina, but decrease it in Senegal. The diverging results provided by the two identi-

\footnotetext{
${ }^{4}$ The marital status of a household can influence its agricultural production through the quantity and quality of inputs available to its production and through the use it makes of these inputs. We only focus on the second possibility in this paper.
} 
fication strategies are reconcilable if the effects of polygyny on the intrahousehold efficiency are only felt in the longer term. But even under this assumption, the longer term effect of polygyny remains different in Burkina Faso and Senegal.

The paper is organized as follows; the next section discusses polygyny and family farming in West Africa. Section 3 briefly reviews the implications of intrahousehold efficiency for agricultural decisions. The approach for estimating the causal effect of polygyny is presented in section 4. Section 5 then presents the main empirical features of our samples. Finally, the empirical results are exposed in Section 6.

\section{Polygyny and agriculture in West Africa}

As shown in Table 1, male polygyny rates are quite high in West Africa. The proportion of married men in union with more than one wife reaches $29 \%$ in Benin and Burkina Faso, and 20\% in Senegal. Even in countries where polygyny is outlawed, which is in fact the case in more than half of the countries in West Africa, polygyny rates are above 15\% (with the exception of Liberia). There are primarily two reasons behind the high rates of polygyny observed in countries where it is forbidden. First, civil laws against polygyny are not enforced (Tertilt, 2006) and second, polygamous unions are still permitted under customary laws in many of these countries (CEDAW, 2005). In fact, three types of marriage are generally possible in West Africa : traditional, religious and civil. Each type involves different rights and obligations. Traditional marriages, which are usually the most common, do not restrict the number of spouses a man may have. Muslim marriages limit the number of wives to four, while Catholic marriages authorize only one spouse (Boyer et al., 1991). However, it is not unusual to encounter a Catholic man who has chosen a traditional marriage over a Catholic one in order to marry more than one woman. ${ }^{5}$ In all West African countries, bigamy is by far the most common form of polygyny.

These high rates of polygyny do not, however, imply that many West African women choose

\footnotetext{
${ }^{5}$ In a survey conducted by the author in Burkina Faso in 1998, 14\% of the polygamous men in the sample declared themself to be Catholic. See Dauphin et al. (2011) for more details on this survey.
} 
polygyny. In fact, women often do not have the right to make any decisions about their own marriages, it is their families who have this entitlement with the father frequently having the greatest say (Boyer et al., 1991). Forced marriage is banned in the civil law of many countries, but once again traditional rules often allow this (CEDAW, 2005). Some women are said to see polygyny as a good thing because it allows wives to share the burdens of domestic work (Ware, 1979). They may even form a coalition against the husband in some occasions (Bastide, 2012). ${ }^{6}$ In contrast, many women report not being pleased by the idea of sharing the household resources with a co-wife (Ware, 1979) and fear that their husband could set them aside for the newer wife (Jankowiak et al., 2005). Jealousy between co-wives is mentioned in numerous anthropological papers. ${ }^{7}$ Tensions can be so high between co-wives that they will accuse each other of witchcraft, particularly if one of their children dies (Bastide, 2012). Perhaps to deal with the aversion of the first wife toward the arrival of a new and younger wife, the social norm in many ethnic societies is to give the first wife some prerogatives and authority over the second (Lallemand, 1977; Rookhuizen, 1986; Bastide, 2012). Furthermore, a rule of rotation between the wives for cooking responsibilities and conjugal obligations is typically in place to ensure, in principle, that the wives receive equal treatment from their husband (Madhavan, 2002). Is it also common for cowives to have their own huts and sometimes even their own kitchens (Wittrup, 1990; Bastide, 2012), again probably with the objective of reducing conflicts.

Except for Mauritania, as shown in Table 1, polygyny is more prevalent in rural regions than in urban ones. One reason for this might be that polygyny is a source of opulence for men when women and children contribute significantly to the household wealth, which is the case in rural agricultural households of West Africa. The important role that women play in agriculture in Africa is legendary. They are reported to be, in many cases, the main family member responsible for the sowing, weeding, harvesting, transportation and transformation of the crops, leaving the men to do the clearing of the land, as well as the ploughing and spraying (Saito, 1994; FAO, 2011b). This high division of labor between men and women, combined with the lack of

\footnotetext{
${ }^{6}$ This reality is reflected in the Nigerian proverb: "Herd unity requires the lion to sleep on an empty stomach." (Free translation of the author).

${ }^{7}$ See for example Calame-Griaule (1986), Potash (1989), Wittrup (1990), McIlwraith (1992), Madhavan (2002).
} 
agricultural labour market for female labour (Fafchamps, 1993; Traoré, 2010; FAO, 2011a), could make polygyny particularly attractive for agricultural men wanting to increase their workforce (Boserup, 1970; Singh, 1988; Jacoby, 1995).

Land, a fundamental input for agriculture, is governed in West African countries by state land laws and by customary land rights which often dominate in rural areas. While the details of traditional land rights vary within ethnic groups, in general, they all recognize "possession" rights. That is, ownership falls to the original occupants who initially cleared and exploited the land in question (Feder and Noronha, 1987). A "landlord"8 is often in charge of controlling the land and of allocating it to the male members of the lineage (Verdier, 1971). If the land allotted to a man is insufficient, he may try to borrow some land from another family group. Since individuals may lose their customary land rights when it is not exploited (Feder and Noronha, 1987), they may be ready to lend or rent it when it is not being used (Traoré, 2010). Traoré (2010) even reports a practice of "false fields", which consists of pretending that a field is cultivated in order not to lose it. This rule of occupancy governing customary land rights may also encourage polygyny and fertility (Boserup, 1970). Generally, married women gain access to land through husbands who have granted them a portion of their own land (Saito, 1994). The literature on women in agriculture widely reports that the parcels of land granted to women this way is of low quality. ${ }^{9}$ In many Burkina Faso ethnic groups, there are often portions of fields that the husband recently left fallow due to declining productivity (Traoré and Fourgeau, 2006).

Agricultural households usually cultivate several dispersed parcels of land at the same time. The parcels are only partially specialized in the production of a crop. The same crops are frequently cultivated on different parcels at the same time. Women are mostly active in food crops, while cash crops are dominated by men. Often, some of the parcels cultivated are called family fields and others personal fields. The literature on family agriculture organization mentions that all the members of the household must work on the family fields and that harvests from these are

\footnotetext{
${ }^{8}$ The expression in French is "chef de terre".

${ }^{9}$ See for example, Riss (1989) and Traoré and Fourgeau (2006).
} 
intended for the consumption of the household and to fulfill family obligations. ${ }^{10}$ Agricultural operations and the use of the family field harvests would be subject however to the authority of the head of the household. Only after having completed their tasks on the family fields would the other household members be allowed to cultivate their personal fields. ${ }^{11}$ The priority given to family fields are reported to delay the timing of agricultural operations on personal fields and reduces the intensity of their cultivation (Riss, 1989; Traoré, 2010). While wives must help their husbands with family fields, men may also help their wives with their personal fields, especially for tasks demanding physical strength. However, mutual aid between co-wives for cultivating their personal fields does not seem to be frequent (Schlippé, 1956; Traoré, 2010). ${ }^{12}$ The harvests of personal fields generally belongs to the cultivator and are partly intended for family consumption and partly for earning income.

This description of the organization of farm households suggests that the allocation of inputs is governed by social norms potentially in contradiction with the maximization of the household's total agricultural production. This could lead to output loss and make agricultural decisions inefficient. It also suggests that polygamous households are not more efficient in allocating their inputs. The next section proposes testable restrictions of these two assumptions.

\section{Assessing intrahousehold efficiency of agricultural decisions}

As with Akresh et al. (2012a,b), the approach we follow for assessing the intrahousehold efficiency of agricultural production is that proposed by Udry (1996). The advantage of this method is that the degree of inefficiency is measured, and this allows us to test whether polygamous households are more inefficient than monogamous ones. The approach developed by Chiappori and his

\footnotetext{
${ }^{10}$ This is in fact the definition of a farm household employed in many surveys. For example, the following definition was employed by the survey we use for Burkina Faso : "first, that members of a household work jointly on at least one common field under the management of a single decision-maker, and second that members draw an important share of their staple food stuffs from one or more granaries which are under the control of that same decision-maker." (see Matlon, 1988, page. 4)

${ }^{11}$ See for example Riss (1989), Abbas (1997), Kevane and L.C. (1999), Gafsi (1987), Traoré and Fourgeau (2006).

${ }^{12}$ As mentioned previously, mutual aid with domestic chores is however observed between co-wives. There exists a rotation system between women called the "kitchen turns" (Fainzang, 1989).
} 
collaborators for testing the rationality of consumption and labour supply decisions is not appropriate for this kind of test, since it does not allow one to assess the extent of inefficiency. We start by briefly reviewing the implications of efficiency derived by Udry (1996).

Consider a household composed of $I$ individuals engaged in the cultivation of $C$ commodities on plots they control, assuming this is predetermined. The plots cultivated with crop $c$ are indexed by $p_{c}$, with $p_{c}=1_{c}, \ldots, P_{c}$. $A_{p_{c}}$ represents the size of the area of plot $p$ planted with crop $c$ and $\mathbf{z}_{p_{c}}$ is a vector of the other characteristics of the plot. The household production of crop $c$ is given by:

$$
Y_{c} \equiv \sum_{p_{c}=1}^{P_{c}} \tilde{Y}_{c}\left(L_{p_{c}}^{1}, \ldots, L_{p_{c}}^{I}, L_{p_{c}}^{n}, F_{p_{c}} ; A_{p_{c}}, \mathbf{z}_{p_{c}}\right)
$$

where $L_{p_{c}}^{i}$ is the labour of individual $i$ devoted to the production of crop $c$ on plot $p_{c}, L_{p_{c}}^{n}$ is nonfamily labour employed and $F_{p_{c}}$ is the amount of fertilizer used. ${ }^{13}$ The production function $\tilde{Y}_{c}($. implicitly allows a gender-based division of work. Furthermore, the technology is permitted to vary across crops, but not within a crop. More specifically, it implies that the same production technology is available to cultivate crop c on the different plots. The total amount of labour devoted to the culture of crop $c$ by individual $i$ and non-family members is denoted by $L_{c}^{i} \equiv \sum_{p_{c}=1}^{P_{c}} L_{p_{c}}^{i}$ and $L_{c}^{n} \equiv \sum_{p_{c}=1}^{P_{c}} L_{p_{c}}^{n}$. Similarly, the total amount of fertilizer used for crop $c$ is designated by $F_{c} \equiv \sum_{p_{c}=1}^{P_{c}} F_{p_{c}}$.

Productive efficiency requires that the inputs devoted to the production of a crop be allocated across the plots planted with the crop in a way that maximizes the total production of the crop. ${ }^{14}$ Formally, given the plots that were chosen for planting crop $c$, the total amount of work provided to the production of $\operatorname{crop} c$, that is $\left(L_{c}^{1 *}, \ldots, L_{c}^{I *}, L_{c}^{n *}\right)$, and the total amount of fertilizer used for that crop $F_{c}^{*}$, then $\left\{L_{1_{c}}^{1 *}, \ldots, L_{P_{c}}^{1 *}, \ldots, L_{1_{c}}^{I *}, \ldots, L_{P_{c}}^{I *}, L_{1_{c}}^{n *}, \ldots, L_{P_{c}}^{n *}, F_{1_{c}}^{*}, \ldots, F_{P_{c}}^{*}\right\}$ is efficient only if it is a solution to the following maximization problem:

\footnotetext{
${ }^{13}$ To be more comprehensive, the list of variable inputs should also include water, pesticides and seeds; while land and farm equipment should be treated as fixed inputs.

${ }^{14}$ Unless household production decisions are separable from household consumption decisions, productive efficiency is a necessary condition for overall efficiency.
} 


$$
\begin{aligned}
& \operatorname{Max} \sum_{p_{c}=1}^{P_{c}} \tilde{Y}_{c}\left(L_{p_{c}}^{1}, \ldots, L_{p_{c}}^{I}, L_{p_{c}}^{n}, F_{p_{c}} ; A_{p_{c}}, \mathbf{z}_{p_{c}}\right), \\
& \text { subject to } \quad L_{c}^{i *}=\sum_{p_{c}=1}^{P_{c}} L_{p_{c}}^{i} \quad i=1, \ldots, I \\
& L_{c}^{n *}=\sum_{p_{c}=1}^{P_{c}} L_{p_{c}}^{n} \\
& F_{c}^{*}=\sum_{p_{c}=1}^{P_{c}} F_{p_{c}}, \\
& L_{p_{c}}^{i} \geq 0, L_{p_{c}}^{n} \geq 0, F_{p_{c}} \geq 0,
\end{aligned}
$$

where we assume that $\widetilde{Y}_{c}($.$) is concave, increasing with \left(L_{p_{c}}^{1 *}, \ldots, L_{p_{c}}^{I *}, L_{p_{c}}^{n *}\right)$, increasing with $F_{p_{c}}$ up to some point, than decreasing afterwards and finally strictly increasing in $A_{p_{c}}$. Clearly, for a solution of program (P) to occur, inputs must be allocated across the plots in order to equalize their marginal products. This applies to the $C$ crops. Since technology is assumed to be the same, two plots sharing the same characteristics, for example $A_{1_{c}}=A_{2_{c}}$ and $\mathbf{z}_{1_{c}}=\mathbf{z}_{2_{c}}$, will get the same level of inputs and therefore will produce the same level of output. This implies that variations in inputs and output across plots planted with the same crop $c$ are fully caused by variations in the plots' characteristics. This result forms the basis of Udry's test of efficiency. Formally, it can be stated as follows:

Proposition 1 If the same production function is used for a given crop, and if $\widetilde{Y}_{c}($.$) is concave,$ increasing with $\left(L_{p_{c}}^{1 *}, \ldots, L_{p_{c}}^{I *}, L_{p_{c}}^{n *}\right)$, increasing with $F_{p_{c}}$ up to some point, than decreasing afterwards and finally strictly increasing in $A_{p_{c}}$, then the program $(P)$ implies that within a household, deviations in output and inputs across plots planted with the same crop are entirely explained by deviations in the plots' characteristics $A$ and $\mathbf{z}$, that is:

$$
\begin{aligned}
& l_{p_{c}}^{i}-\bar{l}_{p_{c}}^{i}=g_{l_{c}^{i}}\left(A_{p_{c}}-\bar{A}_{c}, \mathbf{z}_{p_{c}}-\overline{\mathbf{z}}_{c}\right) \quad \forall i=1, \ldots I, \\
& l_{p_{c}}^{n}-\bar{l}_{p_{c}}^{n}=g_{l_{c}^{n}}\left(A_{p_{c}}-\bar{A}_{c}, \mathbf{z}_{p_{c}}-\overline{\mathbf{z}}_{c}\right) \\
& f_{p_{c}}-\bar{f}_{p_{c}}=g_{f_{c}}\left(A_{p_{c}}-\bar{A}_{c}, \mathbf{z}_{p_{c}}-\overline{\mathbf{z}}_{c}\right) \\
& y_{p_{c}}-\bar{y}_{p_{c}}=g_{y_{c}}\left(A_{p_{c}}-\bar{A}_{c}, \mathbf{z}_{p_{c}}-\overline{\mathbf{z}}_{c}\right)
\end{aligned}
$$


$\forall p_{c}=1_{c}, \ldots, P_{c}$, where $l_{p_{c}}^{i} \equiv L_{p_{c}}^{i} / A_{p_{c}}$ represents the intensity of the labour input of individual $i$ on plot $p_{c}$ with $\bar{l}_{p_{c}}^{i}$ denoting its mean value over plots cultivated with crop $c$, and so on for the other inputs. Similarly, $y_{p_{c}} \equiv Y_{p_{c}} / A_{p_{c}}$ denotes the yield of plot $p_{c}$ and $\bar{y}_{p_{c}}$ corresponds to its average value over plots planted with crop $c$, and finally $\bar{A}_{c}$ is the mean size of the plots cultivated with crop $c$ and $\overline{\mathbf{z}}_{c}$ is a vector of the means of the other characteristics of these same plots.

The proposition implies that differences in the sex of the person responsible for the plot, or any other characteristics of the person, should not cause differences in input intensity or yield of plots cultivated with the same crop. ${ }^{15}$ Equations (2), (3), (4) and (5) are necessary conditions for efficiency and hold for every crop $c$, every household and at every period. Therefore, if the restriction is rejected, efficiency is rejected. Inefficiency could be observed if social norms regulated the allocation of labour and fertilizer or the use of agricultural equipment across plots under the responsibility of different members, for example, by giving priority to family plots as was reported in the previous section. Efficiency could also be violated if the quality of the labour of the members is higher when they work on the plots they are responsible for. ${ }^{16}$ Under these circumstances, the household level of production will not be at its maximum.

If efficiency is rejected, the magnitude of the coefficient of variables that should not have an impact on input intensity and yield deviations under efficiency, such as the gender of the person responsible for the plot, provides an appraisal of the extent of production inefficiency. ${ }^{17}$ This assessment of productive inefficiency can then be compared for monogamous and polygamous households to determine which of the two mono-poly statuses experiences more inefficiency.

\footnotetext{
${ }^{15} \mathrm{Key}$ to this result is the assumption that the same technology is used on the different plots. Since different household members are responsible for the household plots and because women are less likely to receive training in agriculture than men (Saito, 1994; FAO, 2011b), this may seem questionable. However, the assumption is still reasonable if information and skills are shared within a household. Alternatively, we can go further back in the family decision process to consider the distribution of the plots among household members. If some members have a higher technical knowledge for the cultivation of the crop, then maximization requires that they be the ones responsible for growing the crop.

${ }^{16}$ This could happen if the distribution of consumption between the members depends on the distribution of the production over the plots controlled by the different members. The literature reviewed in the previous section cleary suggests this possibility. Duflo and Udry (2003) also make this point. This, combined with a sexual division of work, could create inefficiencies.

${ }^{17}$ To refine the assessment of inefficiency, the loss of output due to the misallocation of input could be evaluated by estimating a production function. Only the first approach is used in this paper however.
} 


\section{Data}

To test Proposition 1, we use different surveys carried out in three West African countries that experience a high prevalence of polygyny, especially in rural areas : Benin, Burkina Faso and Senegal. The surveys are the only ones we could find that, at the same time, provide detailed information at the plot level and whose samples contain a sufficient number of polygynous households to carry out the analysis.

The Benin data are drawn from the Benin Small Farmer Survey conducted by IFPRI and LARES ${ }^{18}$ between August and November 1998. The objectives of the survey were to provide information on rural livelihoods and on how conditions for farmers had changed over time. The survey collected information on a range of subjects including inputs used in agricultural production, output, the attributes of the land cultivated, such as its size, its main source of water, its distance from the village and the type of land tenure for the main season of 1997 and the small season of 1997-1998. The sampling design was a two-stage stratified random sample. In the first stage, a certain number of villages were randomly selected in each of the six departments forming the country, for a total of 100 villages. The number of villages selected was proportional to the relative contribution of the department to the agricultural production of the country, subject to a minimum of 10 villages per department. In each village, nine households were randomly selected giving a final sample size of 899 agricultural households. Among them, 499 are monogamous and 307 are polygynous, with an average of 2.4 wives for polygamous man as can be seen in Table 2 . Our sample only retained the 806 married households.

A total of 2073 and 1361 plots were farmed respectively by monogamous and polygynous households over the period. More than one crop per plot was cultivated in many cases, leading to 3 354 and 2174 crop-plot observations for the monogamous and polygynous households. The great majority of these crop-plots, that is $95 \%$, was under the responsibility of men. In fact, only 108 married households comprise both female and male cultivators, that is $13 \%$ of the households of our sample, 61 monogamous households and 47 polygamous ones. For the monogamous house-

\footnotetext{
${ }^{18}$ Laboratoire d'analyse régionale et d'expertise sociale in Cotonou, Republic of Benin.
} 
holds, a total of 150 crop-plots controlled by members of the same household with different genders were planted with the same crop. The figure rises to 226 for polygamous households.

The dataset for Burkina Faso is the same as that used by Udry (1996) and Akresh et al. (2012a,b). It comes from a 5-year panel survey called the Burkina Faso Farm Level Studies and carried out by ICRISAT between 1981-1985. The survey was conducted on 150 households dispersed across three agro-climatic zones (Boromo, Djibo and Yako) and six villages. To distinguish our analysis from that of Akresh, Chen and Moore, we retained, like Udry (1996), only the first 3 years $(1981-1983),{ }^{19}$ which is when very detailed agronomic information were collected for each plot cultivated by the households. The information collected ranged from farming operations, inputs and outputs, to the characteristics of the plot cultivated, such as its size, soil type, distance from the village center and its toposequence. ${ }^{20}$ The sample of cultivated plots that were surveyed for the years 1981-1983 included all plots for which the principal crop was a cereal, cotton or a root crop. For plots on which the principal crop was a vegetable or other minor crop, only one plot under the responsibility of the household head and one plot of the senior wife were included. Among the households for which the marital status is known, approximately $51 \%$ of the households were polygamous and the average number of wives per polygamous man was 2.5 over the three years observed (see Table 2).

A total of 1517 and 2440 plots were farmed respectively by monogamous and polygynous households over the period of 1981-1983. More than one crop was often cultivated per plot. Information on the output of the first three main crops of the plot was collected, but since the area devoted to these different crops within the plot was not recorded, yield at the crop-plot level is not available as is the case for Benin. More women do individual cultivation as compared to Benin, with $35 \%$ of the plots being controlled by them. For the monogamous households, over the three years, a total of 318 plots controlled by members with different genders were planted with the same primary crop, in the same year. On the side of polygynous households, 1052 plots controlled by members of diverging genders were planted with the same primary crop, in the same

\footnotetext{
${ }^{19}$ Akresh et al. (2012b) uses the five years, while uses only the years 1984-1985 Akresh et al. (2012a) .

${ }^{20}$ For more details on the survey, see Matlon (1988) and Udry (1996).
} 
year.

The Senegal database comes from a survey called the IFPRI/ISRA Study of Consumption and Supply Impacts of Agricultural Price Policies in the Peanut Basin and Senegal Oriental. As its name suggests, the aim of the survey was to better understand the behavior of rural and urban households in terms of consumption and supply of agricultural products. The sample consisted of twelve representative zones of the Peanut Basin and of the Senegal Oriental, ten of which were rural and two urban. In each of the rural areas, three typical villages were selected and for each of them, twelve households were randomly selected. Each plot cultivated by the rural households of the sample were surveyed and some land characteristics were enumerated, such as the size of the plot cultivated and its tenure. Information on the input and output of its main three crops were recorded over two harvest years, 1989 and 1990. The agricultural data for four of the rural areas are not available however. For three of these areas, the reason is that the data was not captured due to time constraints. In the latter case, the data was discarded due to poor quality.

The size of the sample available for this study amounts to 195 households. Among the married households, $41 \%$ are polygamous and the average number of wives per polygamous household is 2.3 (see Table 2). A total of 633 and 573 plots were farmed by monogamous and polygynous households respectively. In a few cases, more than one crop was cultivated on the plot, which leads to 676 crop-plot observations for the monogamous households and 602 crop-plot observations for the polygamous households. Eighty percent of the plots cultivated were controlled by men. For monogamous households, a total of 237 plots controlled by members of different genders from the same households were planted with the same crop, the same year. The corresponding figure for polygamous households is 338 .

Table 3 presents descriptive statistics on the yields and the areas of plots controlled by men and women for the three countries disaggregated by the mono/poly status. For Benin and Senegal, the yield is defined as the harvest market value of the crop grown on the plot divided by the area of land devoted to this variety. Because the plot area for each of the three major crops is not known for Burkina Faso, the yield is defined instead as the harvest market value of the three 
main crops grown on the plot divided by the area of the plot. For monogamous households, the average yield of male plots is significantly higher than those of females in Benin, but is lower in Burkina, although not significantly. In Senegal, there is no noticeable difference. The picture is similar for polygamous households, but the female-male differential is more pronounced and now significant for Burkina Faso. For each type of marriage in each country, men cultivate plots that are significantly larger than the ones cultivated by women. The difference is particularly pronounced in Burkina Faso, where men can cultivate plots that are 10 times larger than those of women.

Now comparing monogamous with polygamous households, we see that the yield of all plots belonging to monogamous households is significantly lower than those of polygamous households in Burkina and Senegal. In both countries, the yields of male and female cultivators from monogamous households is lower than those of male and female cultivators belonging to polygamous households, although not always significantly according to the $5 \%$ level . Furthermore, we see that the mono-poly differential is higher for female plots than male plots in Burkina Faso, while it is the reverse for Senegal. In Benin, there is no significant difference between the yield of monogamous and polygamous households. Monogamous male cultivators in Benin have yields below their polygamous counterpart, while monogamous female cultivators achieve higher yields than polygamous female cultivators, although none of the gaps are significant. Finally, we note that male and female cultivators from polygamous households tend to grow plots that are significantly larger than those of monogamous male and female cultivators, with the exception of Burkinabe males, where the mono-poly differential is not nearly significant.

This first snapshot on female-male differential and mono-poly differential allows us to discern a few patterns. Men cultivate larger plots in all the settings. Polygamous cultivators, whether male or female, also tend to grow bigger plots. Moreover, polygamous households appear to achieve yields that are at least as good as those of monogamous households. Finally, the average femalemale differential, whether positive or negative, is higher everywhere for polygamous households. 


\section{Estimating the effect of polygyny on agricultural efficiency}

The female-male differential observed for Benin and Burkina may not be the result of an inefficient allocation of inputs. Furthermore the greater female-male differential observed for polygamous households does not necessarily originate from polygyny itself. This section discusses our strategy for estimating the causal effect of polygyny on the intrahousehold efficiency of agricultural decisions.

As seen previously, household production efficiency implies that within a household, variations in yields across plots planted with the same crop are entirely explained by variations in the plots' characteristics. Other exogenous variables have no influence. The female-male comparisons of Table 3 are neither based on variations within households, nor within crops. To ensure that we compare the yields of men and women sharing the same household and cultivating the same crop the same year, we use a household-year-crop fixed effect approach. This may not be sufficient however, since the distribution of plots between the male and the female cultivators of a household is endogenous. Recall that women were reported to receive the plots of lowest quality in the previous section. The effect of a differential between the intrinsic characteristics of the male and female plots will be confounded with the effect of an inefficient allocation of inputs across male and female plots. Our main approach to identify the effect of an inefficient allocation of inputs across male and female plots is to control for all the observed intrinsic characteristics of the plots. The richness of information available varies with the database. It includes for Benin, the area decile, the land tenure, the distance to the compound, and the source of water. ${ }^{21}$ For Burkina Faso, it comprises the area decile, the toposequence, the soil type, and the location of the plot. For Senegal, we only have information on the area decile.

Since we cannot be sure of properly controlling for all the relevant plot characteristics, especially for Benin and Senegal since we have fewer controls, we use a second approach. For Benin, we are able to exploit the fact that a plot is a subdivision of a field. To be more precise, household fields are the basic units in the survey and are frequently subdivided into plots that are not always un-

\footnotetext{
${ }^{21}$ The possibilities are : rain water, irrigation and lowland. Rain water is the excluded category.
} 
der the responsibility of the same household members. If unobserved differences in intrinsic characteristics are more likely to vary across plots belonging to the different fields than across plots belonging to same field, then a field fixed effect should help remove the unobserved heterogeneity in the physical characteristics of the plots. We also know to which field plots belong to in Senegal, but unfortunately all the plots of a field are always under the responsibility of a person of the same sex. ${ }^{22}$

The basic equation to be estimated is thus specified as follows:

$$
y_{p c h t}=\theta F_{p c h t}+\lambda\left(F_{p c h t} P_{h t}\right)+\mathbf{z}_{p c h t} \Theta+\nu_{c h t}+v_{p c h t}
$$

where $y_{p c h t}$ is the yield of plot $p$ planted mainly with crop $c$ and under the control of household $h$ at time $t, F_{p c h t}$ is equal to 1 if the person responsible for the plot is a woman, $P_{h t}$ is equal to 1 if the household is polygamous, $\mathbf{z}_{p c h t}$ is a vector of intrinsic characteristics of the plot, $\nu_{c h t}$ is a household-year-crop fixed effect and $v_{p c h t}$ is an error term. The error term summarizes the influence of unobserved variables and is potentially heteroskedastic. The equation (6) is estimated separately for each country. Note that it is not possible to include the binary variable $P_{h t}$ since it does not vary across plots cultivated by the same household.

The parameter $\theta$ does not represent intrahousehold inefficiency in itself, since it can occur along other lines than the sex of the cultivators, such their status within the household, their agricultural knowledge or intrinsic productivity. To be more precise, $\theta$ represents only the intrahousehold female-male inefficiency. The null hypothesis that monogamous households are efficient corresponds to $\theta=0$. The null hypothesis that polygamous households are efficient is in turn that $(\theta+\lambda)=0$. There are three possible scenarios about the effect of polygyny on efficiency. The first is that polygyny is conducive to efficiency as is argued by Akresh et al. (2012a,b). We would then observe that polygamous households are less inefficient, that is to say that $|\theta+\lambda|<|\theta|$. The second scenario is that polygyny is neutral. This corresponds to a situation where monoga-

\footnotetext{
${ }^{22}$ Note that it is not possible to use the time dimension to control for the effect of unobserved plot characteristics since plots are redrawn each year.
} 
mous and polygamous households are either both efficient or both inefficient to the same extent. This would mean that $\lambda=0$. And finally, polygyny is conducive to inefficiency, leading to the situation where monogamous households are less inefficient, that is $|\theta+\lambda|>|\theta|$.

Polygyny is however endogenous. ${ }^{23}$ In section 2 , it was ascribe to the system of land rights in place and to the productivity of women in agriculture (Boserup, 1970), which was itself related to cropping patterns and the technology available (Jacoby, 1995). While these studies on polygyny are based on variations in the incidence of polygyny across regions, some of the links revealed may also be operational within a region. Men who have access to more productive technology could be less inclined to opt for polygyny. It is also possible that polygamous men choose wives that are known to be particularly productive in agriculture. Since the characteristics that have an effect on the desired number of wives could also have an effect on intrahousehold efficiency, a simple comparison of intrahousehold inefficiency between monogamous and polygamous households could be marred by a selection bias. For example, a household head with better access to productive technology could be less inclined to become polygamist, and at the same time be more able to allocate inputs more efficiently across his plots and his wife's plots. The householdyear-crop fixed effect $\nu_{c h t}$ takes care of such situations since it eliminates the effect of all unobserved household characteristics, that is characteristics that are constant for all the cultivators of the household.

The household-year-crop fixed effect will not, however, capture intrahousehold differentials between male and female cultivators, which poses a threat to the identification of $\lambda$ if this differential varies between monogamous and polygamous households. Let us imagine for example, that men with low intrinsic productivity are more susceptible to choosing a more able wife and also less susceptible to taking a second wife. If the intrahousehold differential of intrinsic productivity between men and women has an effect on intrahousehold inefficiency, then the causal effect of polygyny on female-male intrahousehold inefficiency will not be identified. There is also the

\footnotetext{
${ }^{23}$ Polygyny may be considered exogenous when the reason is the infertility of the first wife or when levirate norms have forced the brother of a deceased man to marry his widow. This would provide a natural experiment, but this information is rarely available.
} 
possibility that greater intrahousehold efficiency makes households richer, which may, in turn, increase the probability that household heads choose to take on a second wife. To deal with these last two possibilities, our main strategy is to use an instrumental variable estimation. We need variables that are correlated with the marital status, but that are not correlated with the differential in female-male characteristics that might be causing the differential in female-male yield. Ethnicity is a plausible candidate since the prevalence of polygyny is well known to vary widely across ethnic groups. ${ }^{24}$ Furthermore, it seems very unlikely that gender differences in the characteristics in question vary from one ethnic group to another. We mentioned in Section 2 that the system of land rights varies from one ethnic group to another, and raised the possibility that it might partially explain the variance in the prevalence of polygamy among ethnic groups. It is also likely that ethnicity, through its system of land rights, influences the average yield of the plots by ethnic groups (Goldstein and Udry, 2008), but what really matters here, is that gender differences in unobserved plot characteristics is not correlated with ethnicity, conditional on a village-year-crop fixed effect. This our key identifying assumption. We can no longer have a fixed effect at the household level in order to properly instrument the mono/poly status. However, to take into account geographical variations, we use a fixed effect at the village level.

Since we cannot have a fixed effect at the household level in order to properly instrument polygyny, the female-male differentials is no longer based on within household variations. This might be particularly problematic for Benin and Senegal, where a small fraction of households include female cultivators. Households with female cultivators might be different from households without female cultivators. One way to eliminate this kind of selection bias is to base the estimation of the female-male differential on households whose mono/poly status change over the periods observed. We implement this approach with the Burkina Faso and Senegal datasets since there are few households that change from monogamy to polygyny or vice versa.

\footnotetext{
${ }^{24}$ This is clearly the case in the three samples we use.
} 


\section{Empirical results}

Starting with Benin, the first column of Table 4 shows that the yield of women's plots is 40 fCFA lower than that of men's plots, when a household-year-crop fixed effect estimation is used along with controls on plot's characteristics. This is less than what was suggested by Table $3 .{ }^{25}$ Plots smaller than the median category are significantly associated with higher yields. Surprisingly, irrigated plots achieve lower yields than those whose main source of water is rain, which may indicate that plots with soils holding less water are selected for irrigation. To investigate the possibility that the effect of an inefficient allocation of inputs is confused with a differential in unobserved intrinsic characteristics between male and female plots, we build on the fact that plots are grouped together in what is called a field. If plots belonging to the same field share more intrinsic physical characteristics than plots belonging to different fields, because they are closer for example, and if plots belonging to a same field are allocated to household members of a different sex, then adding a fixed effect at the field level should help identify the causal effect of the sex of the cultivator. Unfortunately, a very small fraction of fields is composed of both female and male plots. More specifically, there are 57 fields providing variation in the sex of the person responsible for its plots, and these fields belong to 35 households, which represents $33 \%$ of the married households in the sample comprising both male and female cultivators. ${ }^{26}$ The second column of Table 4 presents the results of the estimation with the household-year-crop-field fixed effect. The effect of the being a female cultivator drops by a third with this specification and stops being significant. This evidence is consistent with the literature mentioned earlier reporting that plots allocated to women are of lower quality.

The third column keeps the household-year-crop-field fixed effect, but adds an interaction term

\footnotetext{
${ }^{25}$ Note further that when a household fixed effect specification is used without any controls on plot's characteristics, the female-male differential in Table 3 completely disappears. This result is reported in the first line of the Table 8 in the Appendix. This suggests that there are important differences between households with female cultivators and those without. When controls on plot's characteristics are included in the household fixed effect specification, the female-male differential increases dramatically to -82. Since smaller plots are associated with higher yields, this shows that within households, women tend to cultivate smaller plots than men. If a crop fixed effect is added to the household fixed effect, the female-male differential drops by half to -40, indicating that women tend to cultivate crops that have lower yields. See Table 8 .

${ }^{26}$ Their number is 108 . See section 4 on the data.
} 
between the sex of the cultivator and the marital status of the household. The yield of plots under the responsibility of a woman are found to be 63 fCFA lower than those of men in monogamous households, while they are 9 fCFA higher in polygynous households as reported on the Fem $+F_{e m}^{*}$ Poly line at the bottom of the Table. The negative impact of being a female cultivator in monogamous households is significant, but the positive impact of being a female cultivator in polygamous households is not at all significant. The interaction term itself is positive and significant at the $10 \%$ level. This evidence is coherent with the thesis advanced by Akresh et al. (2012a,b). Since the identification of the effect of gender and of the effect of polygyny on the effect of gender is based on a small number of households, we also provide the results of an estimation dropping the field fixed effect in column 4. The results are indeed quite different. The female-male differential is now lower in monogamous households (-29 compared to -64) and no longer significant, while it is higher (in absolute value terms) in polygamous households (-48 compared to 9) and significant at the $10 \%$ level. This may indicate that there is a female-male differential in unobserved plots' characteristics that is to the advantage of female cultivators in monogamous households, but to their disadvantage in polygamous households.

Since polygyny is endogenous, it is indeed possible that the estimated difference between monogamous and polygamous households in terms of the female-male differential may be caused by unobserved differences between male and female cultivators that are specific to the marital status. As mentioned in the previous section, it may be that less productive men try to compensate by choosing more productive wives and by marrying fewer women. If the intrahousehold differential of intrinsic productivity between men and women has an effect on intrahousehold inefficiency, then the causal effect of polygyny on intrahousehold female-male inefficiency will not be identified. It is also possible that greater intrahousehold efficiency makes household heads wealthier, which may in turn increase the probability that he will be able to pay the brideprice of an additional wife. To deal with this possibility, we use an instrumental variable strategy. We rely on the variation in the prevalence of polygyny across ethnic groups and on the fact that ethnicity is exogenous. 
The fifth column reports the first stage regression for the interaction term on gender and polygyny, Fem*Poly, with a village-year-crop fixed effect specification and three excluded instruments: two dummy variables and the interaction of one of the dummies with the gender of the cultivator. The two dummies respectively concern the Adja and Nago ethnic groups, which account for $9 \%$ and $8 \%$ of the households in the sample, making them the third and fourth most important ethnic groups. Only the Fon and the Bariba are more populous, respectively representing $20 \%$ and $15 \%$ of the households in the sample. Among all the ethnic groups, the Adja are those that experience the highest rate of polygyny. The third excluded instrument is therefore an interaction term between the Adja ethnic group and the sex of the cultivator. Two of the excluded instruments are individually highly significant. Moreover, the three instruments are overidentifying. Since we are only interested in the Fem* Poly endogenous variable - the endogenous variable Poly being more a kind of control - we report the Angrist-Pischke first-stage F statistics instead of the Cragg-Donald statistics. The Angrist-Pischke first-stage F statistics for the three instruments is 118, allowing us to reject the possibility that they are weak instruments for Fem*Poly. For space reasons, the results of the first stage regression for the variable Poly are presented in Table 7 in the Appendix along with other test statistics. The last column of Table 4 shows a female-male yield differential similar to the one estimated with the third specification, but a negative effect for polygyny, although none of the coefficients are significant. The effect of polygyny itself on yield is also insignificant. One should note that this female-male differential is not based anymore on within household variations, which could pose a problem and may explain why significance is gone. ${ }^{27}$ This first piece of evidence based on Benin is thus not really conclusive.

We now turn to the results obtained for Burkinabe households for the years 1981-1983. The first column of Table 5 presents the results of an estimation using the same specification as Udry (1996), ${ }^{28}$ with the same sample, the only difference being that it is limited here to married households. We see that the plots of women have a yield 31 fCFA lower than those of men, when a household-year-crop fixed effect specification is used with controls on plot characteristics. Given

\footnotetext{
${ }^{27}$ Especially, given that it was reported in footnote 28 that the female-male differential based on within housheold variation is much different from the one that is not restricted to that variation.

${ }^{28}$ See column 1 of his Table 3.
} 
that the average yield is around $82 \mathrm{fCFA}$, this differential is more important in relative terms than that observed for the Benin households. Moreover, it is in the opposite direction from that of the female-male yield differential presented in Table $3{ }^{29}$ As is the case with Benin, plots smaller than the median category are significantly associated with higher yields, while plots larger than the median are significantly associated with lower yields. The other controls on plot characteristics are generally not significant. ${ }^{30}$

The introduction of the interaction term between sex and polygyny does not alter the effect of the gender's cultivator on yield. The coefficient is maintained around -31 fCFA and stays significant. The interaction term is not nearly significant. Therefore, efficiency is rejected for both monogamous and polygamous households, and the assumption that polygamous households are equally inefficient can not be rejected. This does not mean however, that the marital status is without an effect on the intrahousehold efficiency. It could be that polygyny decreases efficiency, but that more efficient households are more susceptible to becoming polygamous for example, the two effects cancelling each other out. One way to eliminate this selection bias is to exploit the information provided by households whose marital status changes over time. This allow us to compare the same households before and after the change in the marital status. They are, however, only 9 households to change from monogamy to polygyny or vice versa, during the three years observed. To capture the variation in the mono/poly status through the years, we remove the time dimension of the household fixed-effect. More specifically, we used a household fixed-effect estimation and a separate village-year-crop fixed effect. The results are reported in the third column of Table 5. Polygyny is found to adversely affect yields, at least in the short term. In addition, its harmful effect seems to be felt as much on male plots as on female plots, since the inter-

\footnotetext{
${ }^{29}$ In fact, the positive gap of 18 fCFA presented in Table 3 does not change much when a household fixed effect specification is used without any controls on plot characteristics See Table 9 in the Appendix. When controls on plot characteristics are included in a household fixed-effect specification, the female-male yield differential is completely reversed and almost twice as big in absolute value terms. As with Benin this is due to the fact that woman tend to cultivate smaller plots, which are associated with higher yields. The much more pronounced effect obtained, compared to the Benin results, is coherent with the fact, reported earlier, that the difference between the area of male and female plots is much more pronounced in Burkina Faso. Finally, once a crop fixed-effect is added to the household fixed effect, the female-male yield differential drops slightly, indicating that women tend to cultivated crops that have lower yields than men, but not to the extent found for Benin. See Table 9.

${ }^{30}$ Furthermore, we could not reject the hypothesis that their joint effect on yield is different from zero.
} 
action term is not significantly different from zero. Based on these results, we cannot reject the hypothesis that polygyny has no effect on female-male intrahousehold inefficiency.

Since the identification is based on a very small sample of households, we also perform an IV estimation as was done for Benin. The variables used to instrument the variables Poly and Fem*Poly are again two dummy variables on ethnicity and an interaction term between one of the dummy variables and the gender of the operator. The dummies are for the Rimaibe and the Mossi ethnic groups, accounting for $19 \%$ and $38 \%$, respectively, of the households in the sample. Polygyny is widespread in all the ethnic groups in the sample, except with the Rimaibe where it is virtually absent. The interaction term is therefore between this ethnic group and the gender of the cultivator. Column 4 of Table 5 presents the first-stage regression of the variable Fem ${ }^{*}$ Poly. The three excluded instruments are individually significant and jointly overidentifying. Based on the Angrist-Pischke first-stage F statistics, we strongly reject that they are weak. See Table 7 in the Appendix for the results of the first-stage regression of Poly. The last column provides the results of the IV estimation. With this specification, the yields differential between male and female plots in monogamous households is twice as high as in the other columns. Furthermore, polygyny appears to almost eliminate that differential. Since polygyny does not have a significant effect on yields, the elimination of the gap between the performance of male and female plots appears to take the form of both an increase in the performance of female plots and a decrease of the performance of male plots. These last results support the possibility put forward by Akresh et al. (2012a,b), but are in contradiction with the results of column 3. One possible explanation would be that polygyny does not change intrahousehold efficiency in the short-term, but improves it in the longer term. Both specifications nevertheless have their drawbacks. The identification in column 3 is based on a very small number of households whose marital status changes over time, while the identification in column 5 is not based on within household variations. ${ }^{31}$

The last set of results concerns Senegal and is presented in Table 6. This dataset is not as rich as

\footnotetext{
${ }^{31}$ Note, as was reported in footnote 32 , that the female-male differential based on within household variation is not much different from the one that is not restricted to that variation. So it may not be a problem here.
} 
the previous ones, so we have fewer control variables. When only the size of the plot is taken into account, the yield of female cultivators is 34 fCFA lower than that of male cultivators based on a household-year-crop fixed effect. This differential represents $64 \%$ of the average yield (53 fCFA), making it the most dramatic gap of the three countries studied in this paper. It could be due to the fact that we have fewer controls. ${ }^{32}$ This picture is very different from that of Table 3 , where there is no noticeable difference between male and female plots. ${ }^{33}$ The pattern observed between the size of the plot and yield is again observed for Senegal. The inclusion of the interaction term between gender and polygyny does not change the coefficient of gender. The interaction term itself is zero. Therefore, the efficiency of agricultural production is thus rejected for both statuses and we can not reject the assumption that polygamous households are as inefficient as monogamous households. The third column tries to isolate the effect of polygyny on intrahousehold efficiency. As is the case for Burkina Faso, the identification is based on households whose marital status changes between the two years observed. However, since there are only 2 households in this situation, we instead exploit the change in the number of wives, assuming that the relationship between the number of wives and intrahousehold inefficiency is monotonic. There are three households whose number of wives increases from 2 to 3 and a fourth household whose number of wives changes from 3 to 4 . We thus have six households in total that experience a change in their number of wives. We remove the time dimension of the household fixed effect in order to capture the variation in the number of wives during the two years. The results of the household fixed-effect estimation with a separate village-year-crop fixed effect are reported in the third column of Table 6 . The effect of the number of wives on yields and on the effect of gender on yields is found to be insignificant, based on the experience of these households.

\footnotetext{
${ }^{32}$ This is not so clear however, since for Burkina Faso, controlling for land characteristics other than size does not change the female-male differential. Furthermore, the hypothesis that these controls are not jointly significant was not rejected.

${ }^{33}$ Like for Burkina Faso, restricting the estimation of the male-female differential to within household variations, does not produce much change. The differential remains quasi-absent as on can see in Table 10. This suggests that households with female cultivators are not different, along this dimension, from households without. When controls on plot characteristics are included in a household fixed-effect specification, the male-female differential increases to -16 and becomes significant. Again, this comes from the fact that women tend to cultivate smaller plots than men. The change is not as dramatic as for Benin and Senegal. Surprisingly, when a crop fixed effect is added to the household fixed effect, the female-male differential doubles, which suggests that women tend to cultivated crops that have higher yields than men. See Table 10 in the Appendix.
} 
As for Burkina, since the identification is based on a very small number of households, we pursue the analysis with an IV approach. Our excluded instruments are two dummies for the Wolof and Diakhanke ethnic groups and an interaction term between the gender of the plot operator and the Wolof ethnicity. Respectively, $44 \%$ and $7 \%$ of the households in the sample belong to these ethnic groups. The prevalence of polygyny is $55 \%$ among the Wolof, the highest among the major ethnic groups listed in the sample. Two of the excluded instruments are individually significant at the $5 \%$ level and the third at the $10 \%$ level in the first-stage regression of Fem ${ }^{*}$ Poly. The Angrist-Pischke F statistic is high enough to reject the hypothesis that the instruments are weak and the Hansen statistic allows us to reject the hypothesis that the residuals are correlated with the excluded instruments. See Table 7 in the Appendix for the results of the first-stage regression of Poly. Based on the results of the IV estimation, polygyny causes a yield improvement. It appears however, at the same time, to increase the differential between male and female plots, with a $10 \%$ level of confidence, as though only plots under the responsibility of men benefited from polygyny. ${ }^{34}$ Furthermore, with this specification, efficiency is not rejected for monogamous households, only for polygamous ones. This evidence is in conflict with the theory proposed by Akresh et al. (2012a,b).

The evidence presented for the three countries on the causal effect of polygyny is mixed. The IV results for Benin do not allow us to reject the assumption that polygyny has no effect on intrahousehold efficiency. Our confidence in the identification of the causal effect is not too high however. In Burkina Faso, the causal effect is estimated with two different approaches. When the identification is based on a small number of households experiencing a change in their mono/poly status, we find that polygyny has no effect on intrahousehold efficiency. When the identification instead relies on an instrumental approach, we find that polygyny improves intrahousehold efficiency. For Senegal, like for Burkina Faso, we do not reject that polygyny has no effect on intrahousehold efficiency when we rely on the experience of households whose number of wives changes between the two periods observed. But, as opposed to Burkina, the IV results show that

\footnotetext{
${ }^{34}$ This male-female differential is not based on within household variations, but, as was reported in footnote 33 , since the differential based on within household variation and the one that is not are very similar, this might not be an issue.
} 
polygamy deteriorates intrahousehold efficiency.

The diverging results provided by the two identification strategies could be reconciled if the effects of polygyny on the intrahousehold efficiency are only felt after some time. Even in this case, the effect of polygamy in the medium and long terms would still be different in Burkina Faso and Senegal. This is not impossible however since the effect of polygamy could be culturally specific. The theory put forward by Akresh et al. (2012a,b) may therefore be valid only in some contexts.

\section{Conclusion}

Polygyny is a highly debated subject. For some, it is a practice with deep roots in African history which has allowed women to marry in periods of deficit in the number of men due to higher male mortality. For others, it is a form of discrimination towards women that has negative consequences on the life of women married to polygamous men. Many anthropologists have indeed provided evidence that polygyny is conducive to conflicting behaviors, ranging from verbal and physical aggression to poisoning (DuBois, 1960; LeVine, 1962; Flinn and England, 1995; Jankowiak et al., 2005; Kazianga and Klonner, 2009). Some studies also find that polygyny has adverse impacts on the physical and mental health of wives and their children (Sellen, 1999; Arney, 2002; Hadley, 2005; Al-Krenawi and Graham, 2006; Kazianga and Klonner, 2009).

Many countries now prohibit polygyny and those where it is still legal are under pressure to ban it. Until now, pressure has mostly been based on the discrimination argument. However, a small amount of recent literature linking the marriage system of a country to its level and rate of development (Lagerlof, 2005; Tertilt, 2005, 2006; Edlund and Lagerlof, 2004; Gould et al., 2008) might provide ammunition to those opposing polygyny in Africa. Tertilt (2005) for example shows that polygyny crowds-out investments in physical assets and increases fertility. She finds that banning polygyny would decrease fertility by $40 \%$, increase saving by $70 \%$ and increase output per capita by $170 \%$ in countries with a high incidence of polygyny. The papers by Akresh et al. (2012a,b) point however in the other direction. They argue that polygyny may increase intrahousehold efficiency and provide supportive evidence. They ascribe the efficiency improvement to the fact that 
altruism is lower in polygamous marriages, since wives do not generally care for each other. This lower altruism, they say, increases the incentive of spouses to cooperate by lowering the utility they expect to receive in a non-cooperative equilibrium.

The contribution of this paper is to provide new empirical evidence on whether polygyny leads to an improvement in intrahousehold efficiency. We study the intrahousehold efficiency of agricultural production of three countries with high levels of polygyny : Benin, Burkina Faso and Senegal. The causal effect of polygyny is tentatively estimated with two different strategies : an approach based on the experience of households going through a change in its number of wives and an IV approach relying on the relationship between polygyny and ethnicity. Both approaches are used along with a fixed-effect approach controlling for unobserved confounders.

The evidence we obtain is mixed. For Benin, the assumption that polygyny has no effect on intrahousehold efficiency is not rejected. For Burkina Faso and Senegal, we again do not reject the assumption that polygyny has no effect on intrahousehold efficiency with the first identification strategy. However, based on the IV approach, we reject the assumption for both countries. Moreover, we find that polygyny improves intrahousehold efficiency in Burkina, but deteriorates it in Senegal. The diverging results provided by the two identification strategies could be reconciled if the effects of polygyny on the intrahousehold efficiency are only felt in the longer term. But even under this assumption, the longer term effect of polygyny would remain different in Burkina Faso and Senegal. We conclude that the effect of polygamy could be culturally specific. Therefore, the theory put forward by Akresh et al. (2012a,b), that polygyny may increase intrahousehold efficiency, may be valid only in some limited contexts. 


\section{References}

Abbas, J. Dey (1997) "Gender asymmetries in intrahousehold resource allocation in sub-Saharan Africa: Some policy implications for land and labor productivity," Intrahousehold Resource Allocation in Developing Countries, pp. 249-262.

Akresh, R., K. Chen, and C. Moore (2012a) "Altruism, cooperation, and efficiency : Agricultural production in polygynous households," Working paper, Department of Agricultural, Environmental and Development Economics, The Ohio State University.

(2012b) "Productive efficiency and the scope for cooperation in polygynous households," American Journal of Agriculture and Economics, Vol. 94(2), pp. 395-401.

Al-Krenawi, A. and J. R. Graham (2006) "A comparison of family functioning, life and marital satisfaction, and mental health of women in polygamous and monogamous marriages," International Journal of Social Psychiatry, Vol. 52(1), pp. 5-16.

Arney, F.K. (2002) "Polygyny and child survival in sub-Saharan Africa," Social Biology, Vol. 49, pp. $74-89$.

Ashraf, N. (2009) "Spousal control and intra-household decision making: An experimental study in the Philippines," American Economic Review, Vol. 99(4), pp. 1245-1277.

Bastide, R. (2012) "Polygamie," Encyclopédie Universalis.

Basu, K. (2006) "Gender and say: A model of household behaviour with endogenously determined balance of power," The Economic Journal, Vol. 116(511), pp. 558-580.

Becker, G. (1974) "A theory of marriage: Part II," The Journal of Political Economy, Vol. 82(2), pp. S11-S26.

Bergstrom, T. (1994) "On the economics of polygyny," unpublished manuscript, Department of Economics, UCSB, UC Santa Barbara. 
Bloch, F. and V. Rao (2002) "Terror as a bargaining intrument: A case study of dowry violence in rural india," American Economic Review, Vol. 92(4), pp. 1029-1043.

Boserup, E. (1970) Women's role in economic development: St. Martin, pp.283.

Boyer, A., K. Hill, S. Isaacs, and D. Gordis (1991) "Marriage law and practice in the Sahel," Studies in Family Planning, Vol. 22(6), pp. 343-349.

Calame-Griaule, G. (1986) Words and the Dogon world: Institute for the Study of Human Issues Philadelphia.

CEDAW (2005) "Report of the commitee on the elimination of discrimination against women," Technical report, United Nations.

Dauphin, A., B. Fortin, and G. Lacroix (2011) "Is behavior rational within polygamous households?", Working paper, Département des sciences sociales, Université du Québec en Outaouais.

DuBois, C. (1960) The poeple of Alor: A social-psychological study of an east Indian island: Harvard University Press.

Duflo, E. and C. Udry (2004) "Intrahousehold resource allocation in Côte d'Ivoire: Social norms, separate accounts and consumption choices," May, unpublished manuscript, Department of Economics, MIT.

Edlund, L. and N.-P. Lagerlof (2004) "Implications of marriage institutions for redistribution and growth," unpublished manuscript, Department of Economics, Colombia University.

Fafchamps, M. (1993) "Sequential labor decisions under uncertainty: and estimable household model of West-African farmers," Econometrica, Vol. 61(5), pp. 1173-1197.

Fainzang, S. (1989) La femme de mon mari : étude du mariage polygamique en Afrique et en France: L'Harmattant.

FAO (2011a) "The role of women in agiculture," Technical report, United Nations. 
(2011b) "The state of food and agriculture. Women in agriculture - Closing the gender gap for development," Technical report, United Nations.

Feder, G. and R. Noronha (1987) "Land rights systems and agricultural development in subSaharan Africa," The World Bank Research Observer, Vol. 2(2), pp. 143-169.

Flinn, M.V. and B. G. England (1995) "Childhood stress and family environment," Current Anthropology, Vol. 36(5), pp. 854-866.

Gafsi, M. (1987) "African feminism: a worldwide perspective," in M.-H. Granié and H. GuétatBernard eds. Women in Africa and the African diaspora: Presses Universtaires du Miral, pp. $3-24$.

Goldstein, M. and C. Udry (2008) "The profits of power: Land rights and agricultural investment in Ghana," Journal of Political Economy, Vol. 116(6), pp. 981-1022.

Gould, E.D., O. Moav, and A. Simhon (2008) "The mystery of monogamy," American Economic Review, Vol. 98(1), pp. 333-357.

Grossbard, A. (1978) "Towards a marriage between economics and anthropology and a general theory of marriage," The American Economic Review, Vol. 68(2), pp. 33-37.

Hadley, C. (2005) "Is polygyny a risk factor for poor growth performance among Tanzanian agropastoralists?" American Journal of Physical Anthropology, Vol. 126, pp. 471-480.

Jacoby, H.G. (1995) "The economics of polygyny in sub-Saharan Africa: Female productivity and the demand for wives in Côte d'Ivoire," Journal of Political Economy, Vol. 103(5), pp. 938971.

Jankowiak, W., M. Sudakov, and C. Wilreker (2005) "Co-wife conflict and co-operation," Ethnology, Vol. 44(1), pp. 81-98.

Kazianga, H. and S. Klonner (2009) "The intra-household economics of polygyny: Fertility and child mortality in rural Mali," Munich personal RePEc archive, Vol. 95, pp. 137-156. 
Kevane, M. and Gray L.C. (1999) “A woman's field is made at night: Gendered land rights and norms in Burkina Faso," Feminist Economics, Vol. 5(3), pp. 1-26.

Lagerlof, N.-P. (2005) "Sex, equality, and growth," Canadian Journal of Economics, Vol. 38(3), pp. $807-831$.

Lallemand, S. (1977) "Une famille Mossi,” Technical report, Recherche Voltaïque.

LeVine, R.A. (1962) "Witchcraft and co-wife proximity in southwestern Kenya," Ethnology, Vol. 1(1), pp. 39-45.

Ligon, E., J.P. Thomas, and T. Worrall (2002) "Informal insurance arrangements with limited commitment: Theory and evidence from village economies," The Review of Economic Studies, Vol. 69(1), pp. 209-244.

Lundberg, S. and R. Pollak (1993) "Separate spheres bargaining and the marriage market," Journal of Political Economy, Vol. 101(6), pp. 988-1010.

- (2003) "Efficiency in marriage," Review of Economics of the Household, Vol. 1, pp. 153-

167.

Madhavan, S. (2002) "Best of friends and worst of enemies: Competition and collaboration in polygyny," Ethnology, Vol. 41(1), pp. 69-84.

Matlon, P. J. (1988) "The ICRISAT Burkina Faso farm level studies: Survey methods and data files," Technical report, Village Level Studies Miscellaneous Papers Series, Economics Group. Hyderabad, India: ICRISAT.

McIlwraith, T. F. (1992) The Bella Coola Indians, Vol. 1: University of Toronto Press.

Potash, B. (1989) "Gender relations in sub-Saharan Africa," Gender and Anthropology: Critical Reviews for Research and Teaching, pp. 198-227.

Riss, M.-D. (1989) Femmes africaines en milieu rural : les Sénégalaises du Sine Saloum: L'Harmattan, pp.11-218. 
Rookhuizen, M. (1986) Femmes de Rana : les besoins et possibilités des femmes d'un village Mossi au Burkina Faso: Série Femmes et Développement, pp.243.

Saito, K.A. (1994) "Raising the productivity of women farmers in sub-Sharan Africa," Technical report, The World Bank.

Schlippé, P. (1956) Shifting cultivation in Africa: The Zande system of agriculture: Routledge and Paul, pp.304.

Sellen, D.W. (1999) "Polygyny and child growth in a traditional pastoral society: The case of the Dagota of Tanzania," Human Nature, Vol. 10, pp. 329-371.

Singh, R.D. (1988) "Economics of the family and farming systems in sub-Saharan Africa: Development perspectives," Boulder, p. 208.

Steady, F.C. (1987) "African feminism: A worldwide perspective," in Women in Africa and the African diaspora: Howard University Press, pp. 3-24.

Tertilt, M. (2005) "Polygyny, fertility, and savings," Journal of Political Economy, Vol. 113(6), pp. 1341-1371.

— (2006) "Polygyny, women's rights, and development," Journal of the European Economic Association, Vol. 4(2-3), pp. 523-530.

Traoré, S. (2010) Les femmes de Bondoukuy au Burkina Faso : pilier économique de l'agriculture: L'Harmattan, pp.9-237.

Traoré, S. and C. Fourgeau (2006) Les peties jachères des femmes : condition féminine et travail agricole au Burkina Faso du sud-ouest: L'Harmattan, pp.11-253.

Udry, C. (1996) "Gender, agricultural production, and the theory of the household," Journal of Political Economy, Vol. 104(5), pp. 1010-1046.

Verdier, R. (1971) "Évolution et réformes foncières de l'Afrique noire francophone," Journal of African Law, Vol. 15(1), pp. 85-101. 
Ware, H. (1979) "Polygyny: Women's views in a traditional society, Nigeria 1975," Journal of Marriage \& Family, Vol. 41(2), p. 185.

Wittrup, I. (1990) "Me and my husband's wife: An analysis of polygyny among Mandinka in the Gambia," Folk, Vol. 32, p. 117. 
Table 1: Polygyny in West Africa

\begin{tabular}{|c|c|c|c|c|c|}
\hline \multirow[b]{2}{*}{ Countries } & \multirow{2}{*}{$\begin{array}{l}\text { Acceptance } \\
\text { of } \\
\text { polygyny }^{a}\end{array}$} & \multirow{2}{*}{$\begin{array}{l}\text { Legality } \\
\text { of } \\
\text { polygyny }^{a}\end{array}$} & \multicolumn{3}{|c|}{$\%$ Men practicing polygyny ${ }^{b}$} \\
\hline & & & All area & Rural area & Urban area \\
\hline Benin & 0.5 & No & $29.3^{c}$ & $30.7^{c}$ & $19.6^{c}$ \\
\hline Burkina Faso & 1 & Yes & $29.5^{d}$ & $33.6^{d}$ & $11.5^{d}$ \\
\hline Cap Verde & - & - & - & - & - \\
\hline Côte-d'Ivoire & 0.5 & No & $16.9^{e}$ & $21.2^{e}$ & $9.5^{e}$ \\
\hline Gambia & 1 & Yes & $35.1^{f}$ & - & - \\
\hline Ghana & 0.5 & No & $18.2^{g}$ & $12.2^{g}$ & $4.1^{g}$ \\
\hline Guinea & 1 & No & $36.7^{i}$ & $40.1^{i}$ & $28.9^{i}$ \\
\hline Guinea-Bissau & 1 & No & - & - & - \\
\hline Liberia & 0.5 & No & $7.6^{j}$ & $9.9^{j}$ & $3.0^{j}$ \\
\hline Mali & 1 & Yes & $27.9^{c}$ & $26.5^{c}$ & $22.1^{c}$ \\
\hline Mauritania & 1 & Yes & $6.2^{k}$ & $4.8^{k}$ & $7.7^{k}$ \\
\hline Niger & 1 & - & $22.0^{c}$ & $22.7^{c}$ & $18.6^{c}$ \\
\hline Nigeria & 1 & No & $18.7^{g}$ & $19.5^{g}$ & $9.0^{g}$ \\
\hline Senegal & 1 & Yes & $20.0^{i}$ & $25.3^{i}$ & $14.3^{i}$ \\
\hline Sierra Leone & 1 & No & $20.1^{g}$ & $21.1^{g}$ & $8.5^{g}$ \\
\hline Togo & 1 & Yes & $24.3^{e}$ & $28.1^{e}$ & $15.7^{e}$ \\
\hline
\end{tabular}

a. 2009 OECD Gender Institution and Development database, 1 : accepted, 0 : not accepted,

b. DHS, except Gambia, c. 2006, d. 2003, e. 1998, f. Tertilt (2005), g. 2008, i. 2005, j. 2007, k. 2001 
Table 2: Households by marital regime

\begin{tabular}{lccc}
\hline \hline & $\begin{array}{c}\text { Benin } \\
\text { average } \\
1997-1998\end{array}$ & $\begin{array}{c}\text { Burkina Faso } \\
\text { average } \\
1981-1983\end{array}$ & $\begin{array}{c}\text { Senegal } \\
\text { average } \\
1989-1990\end{array}$ \\
\hline Number of households in sample & 899 & 145 & 195 \\
Unmarried or unknonw marital regime & 93 & 24 & 12 \\
Married & 806 & 121 & 183 \\
Monogamous & $62 \%$ & $49 \%$ & $59 \%$ \\
Polygamous & $38 \%$ & $51 \%$ & $41 \%$ \\
Number of wives & 2.4 & 2.5 & 2.3 \\
\hline
\end{tabular}


Table 3: Yield and area by country, marital regime and gender

\begin{tabular}{|c|c|c|c|c|c|c|c|}
\hline & \multirow{2}{*}{$\begin{array}{c}\text { All } \\
\text { households }\end{array}$} & \multicolumn{2}{|c|}{$\begin{array}{c}\text { Monogamous } \\
\text { households }\end{array}$} & \multicolumn{2}{|c|}{$\begin{array}{l}\text { Polygamous } \\
\text { households }\end{array}$} & \multicolumn{2}{|c|}{$\mu_{\text {mono }}-\mu_{\text {poly }}$} \\
\hline & & $\begin{array}{c}\text { Yield } \\
\mathrm{k} \text { fCFA }\end{array}$ & $\begin{array}{c}\text { Area } \\
\text { hectares }\end{array}$ & $\begin{array}{c}\text { Yield } \\
\mathrm{k} \text { fCFA }\end{array}$ & $\begin{array}{c}\text { Area } \\
\text { hectares }\end{array}$ & $\begin{array}{c}\text { Yield } \\
\text { (t-stat.) }\end{array}$ & $\begin{array}{c}\text { Area } \\
\text { (t-stat.) }\end{array}$ \\
\hline & \multicolumn{7}{|c|}{ Benin 1997-1998 } \\
\hline \multirow[t]{2}{*}{ All plots } & 258 & 254 & .771 & 266 & .991 & -12 & -0.22 \\
\hline & $(625)$ & $(.925)$ & $(783)$ & $(1.12)$ & $(-.585)$ & $(-.742)$ & $(-.162)$ \\
\hline \multirow[t]{2}{*}{ Female plots } & 188 & 204 & .429 & 176 & .514 & 28 & -.085 \\
\hline & $(218)$ & $(226)$ & $(.398)$ & $(211)$ & $(.521)$ & $(1.08)$ & $(-1.57)$ \\
\hline \multirow[t]{2}{*}{ Male plots } & 263 & 256 & .786 & 273 & 1.03 & -17 & -.244 \\
\hline & $(710)$ & $(636)$ & $(.938)$ & $(813)$ & $(1.15)$ & $(-.801)$ & $(-7.85)$ \\
\hline \multirow{3}{*}{$\begin{array}{l}\mu_{m}-\mu_{f} \\
\text { (t-stat.) }\end{array}$} & -75 & -52 & -.357 & -97 & -.516 & & \\
\hline & $(-4.57)$ & $(-2.23)$ & $(-3.92)$ & $(-9.07)$ & $(-10.69)$ & & \\
\hline & \multicolumn{7}{|c|}{ Burkina Faso 1981-1983 } \\
\hline \multirow[t]{2}{*}{ All plots } & 82.4 & 74.7 & .515 & 87.2 & .502 & -12.5 & .013 \\
\hline & $(159)$ & $(146)$ & $(1.01)$ & $(166)$ & $(.954)$ & $(-2.59)$ & $(.402)$ \\
\hline \multirow[t]{2}{*}{ Female plots } & 94.1 & 82 & .079 & 100 & .110 & -18 & -.031 \\
\hline & $(176)$ & $(140)$ & $(.163)$ & $(191)$ & $(.132)$ & $(-1.97)$ & $(-3.49)$ \\
\hline \multirow[t]{2}{*}{ Male plots } & 76.1 & 71.5 & .703 & 79.3 & .745 & -7.80 & -.042 \\
\hline & $(148)$ & $(148)$ & $(1.16)$ & $(148)$ & $(1.15)$ & $(-1.32)$ & $(-.890)$ \\
\hline \multirow{3}{*}{$\begin{array}{l}\mu_{m}-\mu_{f} \\
\text { (t-stat.) }\end{array}$} & 18.0 & 10.5 & -.624 & 20.7 & -.635 & & \\
\hline & $(3.25)$ & $(1.34)$ & $(-16.72)$ & $(2.82)$ & $(-21.29)$ & & \\
\hline & \multicolumn{7}{|c|}{ Senegal 1989-1990 } \\
\hline \multirow[t]{2}{*}{ All plots } & 53.1 & 46.3 & .766 & 60.7 & .897 & -14.4 & -.131 \\
\hline & $(70.8)$ & $(55.0)$ & $(.768)$ & $(84.4)$ & $(1.05)$ & $(-3.57)$ & $(-2.52)$ \\
\hline \multirow[t]{2}{*}{ Female plots } & 54.9 & 47.5 & .422 & 59.5 & .492 & -12.0 & -.070 \\
\hline & $(63.8)$ & $(45.0)$ & $(.324)$ & $(72.7)$ & $(.355)$ & $(-1.65)$ & $(-1.63)$ \\
\hline \multirow[t]{2}{*}{ Male plots } & 52.6 & 46.1 & .826 & 61.2 & 1.05 & -15.1 & -.224 \\
\hline & $(72.5)$ & $(56.6)$ & $(.806)$ & $(88.6)$ & (1.18) & $(-3.11)$ & $(-3.41)$ \\
\hline$\mu_{m}-\mu_{f}$ & 2.30 & 1.40 & -.404 & -1.70 & -.558 & & \\
\hline (t-stat.) & $(.509)$ & $(.282)$ & $(-8.68)$ & $(-.247)$ & $(-8.90)$ & & \\
\hline
\end{tabular}

Standard deviations are in parentheses when not otherwise stated. 
Table 4: Effect of the marital regime on male-female yield differential - Benin 1998

\begin{tabular}{|c|c|c|c|c|c|c|c|c|c|c|c|c|}
\hline hline & \multicolumn{2}{|c|}{$\begin{array}{c}\text { OLS } \\
\text { household-crop } \\
\text { year fixed effect }\end{array}$} & $\begin{array}{r}\mathrm{C} \\
\text { househol } \\
\text { year fix } \\
\mathrm{Y}\end{array}$ & $\begin{array}{l}\text { S } \\
\text { field-crop } \\
\text { d effect } \\
\text { ld }\end{array}$ & $\begin{array}{r}\mathrm{O} \\
\text { household } \\
\text { year fix } \\
\mathrm{Yi}\end{array}$ & $\begin{array}{l}\text { S } \\
\text { field-crop } \\
\text { d effect } \\
\text { ld }\end{array}$ & $\begin{array}{r}\mathrm{O} \\
\text { househ } \\
\text { year fix } \\
\mathrm{Yi}\end{array}$ & $\begin{array}{l}\text { S } \\
\text { d-crop } \\
\text { d effect } \\
\text { ld }\end{array}$ & $\begin{array}{r}\mathrm{O} \\
\text { villag } \\
\text { year fix } \\
\text { Fem }\end{array}$ & $\begin{array}{l}\text { S } \\
\text {-crop } \\
\text { d effect } \\
\text { Poly }\end{array}$ & $\begin{array}{r}I \\
\text { villag } \\
\text { year fix } \\
\mathrm{Y}\end{array}$ & -crop \\
\hline Fem & $\begin{array}{c}\text { Coef. } \\
-40.16^{* *}\end{array}$ & $\begin{array}{r}\text { Std err. } \\
(19.38)\end{array}$ & $\begin{array}{l}\text { Coef. } \\
-27.60\end{array}$ & $\begin{array}{l}\text { Std err. } \\
\quad(25.39)\end{array}$ & $\begin{array}{c}\text { Coef. } \\
-63.63^{* *}\end{array}$ & $\begin{array}{l}\text { Std err. } \\
(28.97)\end{array}$ & $\begin{array}{l}\text { Coef. } \\
-28.87\end{array}$ & $\begin{array}{r}\text { Std err. } \\
(19.17)\end{array}$ & $\begin{array}{l}\text { Coef. } \\
.5396^{* *}\end{array}$ & $\begin{array}{r}\text { Std err. } \\
(.0297)\end{array}$ & $\begin{array}{l}\text { Coef. } \\
-70.55\end{array}$ & $\begin{array}{r}\text { Std err. } \\
(114.7)\end{array}$ \\
\hline Poly & & & & & & & & & & & 61.22 & (419.8) \\
\hline Fem*Poly & & & & & $72.70^{*}$ & $(43.22)$ & -19.06 & $(32.29)$ & & & -110.9 & $(271.2)$ \\
\hline Size 1 & $159.4^{* *}$ & $(51.00)$ & $195.9^{* *}$ & $(98.51)$ & $194.3^{* *}$ & $(98.52)$ & $159.4^{* *}$ & $(50.97)$ & $-.0123^{*}$ & $(.0074)$ & $498.2^{* *}$ & $(66.86)$ \\
\hline Size 2 & $111.1^{* *}$ & $(28.96)$ & $308.8^{* *}$ & $(150.4)$ & $308.3^{* *}$ & $(150.2)$ & $111.2^{* *}$ & $(28.98)$ & -.0001 & $(.0099)$ & 29.88 & $(50.74)$ \\
\hline Size 3 & $52.40^{* *}$ & $(12.66)$ & $75.49^{* *}$ & $(26.67)$ & $81.76^{* *}$ & $(26.74)$ & $52.00 * *$ & $(12.58)$ & $-.0189^{* *}$ & $(.0079)$ & $56.15^{* *}$ & (17.93) \\
\hline Size 4 & $37.82^{* *}$ & $(17.12)$ & 66.12 & $(67.86)$ & 64.37 & $(67.06)$ & $37.52^{* *}$ & $(17.11)$ & -.0130 & $(.0087)$ & -17.90 & $(30.00)$ \\
\hline Size 6 & 31.42 & $(26.04)$ & 113.0 & $(118.7)$ & 113.2 & $(118.2)$ & 31.16 & $(26.07)$ & -.0105 & $(.0100)$ & -15.77 & $(72.28)$ \\
\hline Size 7 & 17.73 & $(17.23)$ & -19.93 & $(60.13)$ & -24.40 & $(60.08)$ & 18.35 & $(17.34)$ & -.0001 & $(.0066)$ & -27.67 & (23.87) \\
\hline Size 8 & 6.669 & $(15.16)$ & 28.26 & $(23.34)$ & 27.12 & $(22.99)$ & 6.684 & $(15.16)$ & $-.0123^{* *}$ & $(.0055)$ & -15.53 & $(54.01)$ \\
\hline Size 9 & 4.538 & $(12.22)$ & 65.18 & $(47.55)$ & 58.85 & $(45.24)$ & 4.624 & $(12.24)$ & $-.0095^{*}$ & $(.0055)$ & -38.63 & $(53.45)$ \\
\hline Size 10 & -17.26 & (13.38) & -20.71 & $(37.78)$ & -19.55 & $(39.02)$ & -16.94 & $(13.26)$ & -.0088 & $(.0063)$ & -45.76 & (99.10) \\
\hline Distance & 2.703 & $(2.531)$ & 426.0 & $(1596)$ & 134.5 & $(1686)$ & 2.675 & $(2.548)$ & $.0025^{* *}$ & $(.0007)$ & 2.515 & $(5.034)$ \\
\hline Distance $^{2}$ & -.1700 & $(.1143)$ & -38.27 & (152.1) & -10.51 & $(160.7)$ & -.1692 & $(.1146)$ & -.0000 & $(.0000)$ & -.0029 & $(.1375)$ \\
\hline Irrigated & $-22.18^{* *}$ & $(7.864)$ & & & & & $-21.93^{* *}$ & $(7.929)$ & .0113 & $(.0114)$ & 294.3 & $(288.2)$ \\
\hline Lowland & -34.86 & $(49.35)$ & & & & & -35.47 & $(49.33)$ & $-.0209 * *$ & $(.0054)$ & 89.78 & $(78.46)$ \\
\hline Adja & & & & & & & & & $.4672^{* *}$ & $(.0301)$ & & \\
\hline Nago & & & & & & & & & .0029 & $(.0071)$ & & \\
\hline Fem*Adja & & & & & & & & & $-.4642^{* *}$ & $(.0300)$ & & \\
\hline Fem+Fem*Poly & & & & & 9.067 & $(35.59)$ & $-47.94^{*}$ & $(28.41)$ & & & -181.4 & $(218.8)$ \\
\hline Observations & $\overline{52:}$ & & & & & & $\overline{\overline{52}}$ & & $\overline{\overline{52}}$ & & & \\
\hline $\begin{array}{l}\text { Angrist-Pischke I } \\
\text { (Stock-Yogo } 5 \% \\
\text { J-stat. of overide } \\
\text { (P-value) }\end{array}$ & $\begin{array}{l}\text { test of exc } \\
\text { naximal IV } \\
\text { atification }\end{array}$ & $\begin{array}{l}\text { luded inst } \\
\text { relative b } \\
\text { estriction }\end{array}$ & $\begin{array}{l}\text { ruments } \\
\text { ias) }\end{array}$ & & & & & & $\begin{array}{r}\mathrm{F}(2,499 \\
(13\end{array}$ & $\begin{array}{l}=117.8 \\
11)\end{array}$ & $\begin{array}{r}\text { Chi2( } \\
\quad(.8 \\
\end{array}$ & $\begin{array}{l}=.038 \\
56)\end{array}$ \\
\hline
\end{tabular}


Table 5: Effect of the marital regime on male-female yield differential- Burkina Faso 1981-1983

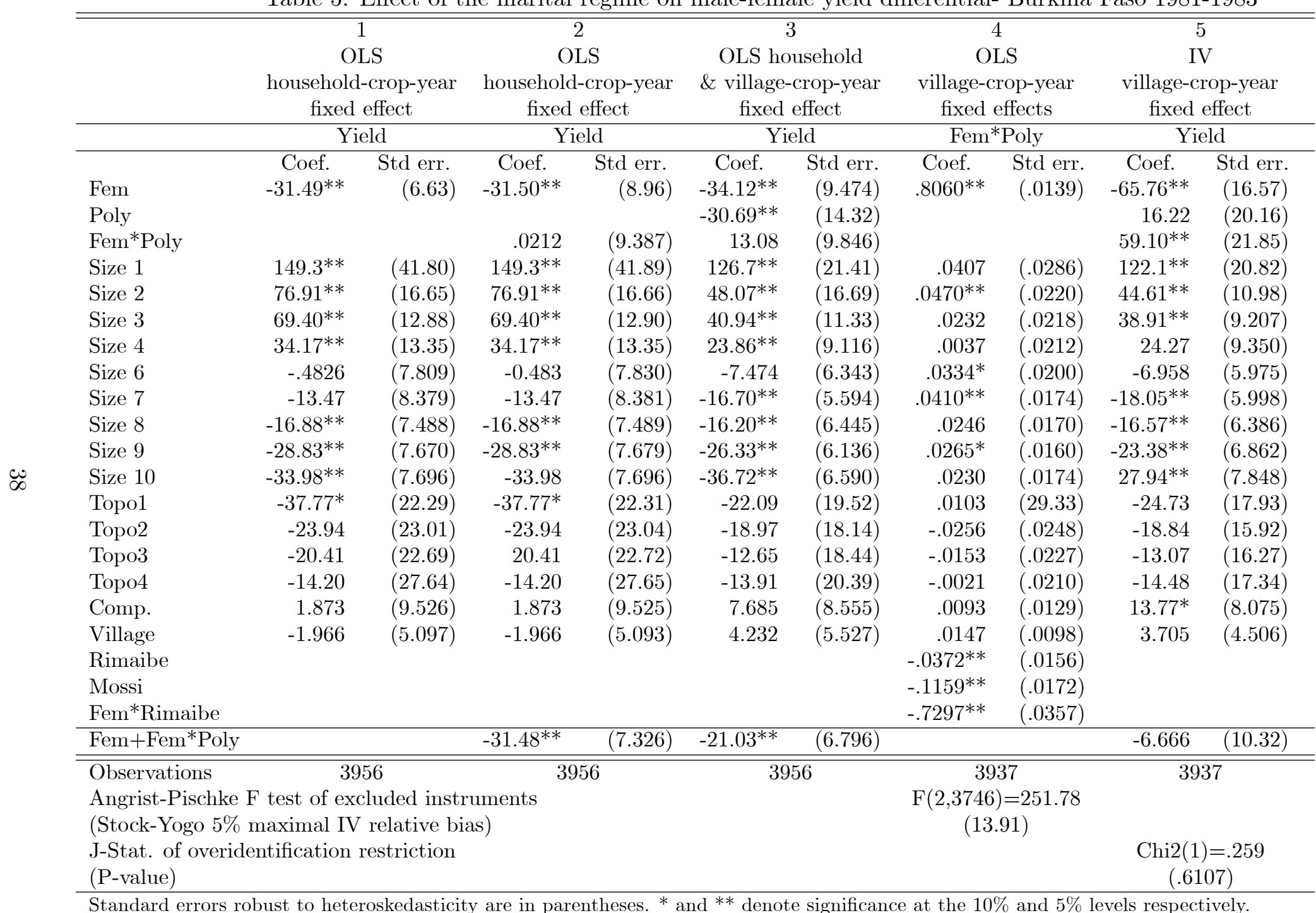

Standard errors robust to heteroskedasticity are in parentheses. ${ }^{*}$ and ${ }^{* *}$ denote significance at the $10 \%$ and $5 \%$ levels respectively.

Coefficients on soil type are not reported for space reasons. 
Table 6: Effect of the marital regime on male-female yield differential - Senegal 1989-1990

\begin{tabular}{|c|c|c|c|c|c|c|c|c|c|c|}
\hline & \multicolumn{2}{|c|}{$\begin{array}{c}1 \\
\text { OLS } \\
\text { household-crop-year } \\
\text { fixed effect }\end{array}$} & $\begin{array}{r}\mathrm{O} \\
\text { household } \\
\text { fixed }\end{array}$ & $\begin{array}{l}\text { S } \\
\text { crop-year } \\
\text { ffect }\end{array}$ & $\begin{array}{r}\text { household } \\
\text { fixes }\end{array}$ & $\begin{array}{l}\text { crop-year } \\
\text { ffect }\end{array}$ & $\begin{array}{r}\mathrm{O} \\
\text { village-c } \\
\text { fixed }\end{array}$ & $\begin{array}{l}\text { S } \\
\text { ffects }\end{array}$ & $\begin{array}{r}\mathrm{I} \\
\text { village-c } \\
\text { fixed }\end{array}$ & $\begin{array}{l}\text { p-year } \\
\text { ffect }\end{array}$ \\
\hline & \multicolumn{2}{|c|}{ Yield } & \multicolumn{2}{|c|}{ Yield } & \multicolumn{2}{|c|}{ Yield } & \multicolumn{2}{|c|}{ Fem*Poly } & \multicolumn{2}{|c|}{ Yield } \\
\hline Fem & $\begin{array}{c}\text { Coef. } \\
-33.52^{* *}\end{array}$ & $\begin{array}{l}\text { Std err. } \\
(7.485)\end{array}$ & $\begin{array}{c}\text { Coef. } \\
-33.64^{* *}\end{array}$ & $\begin{array}{l}\text { Std err. } \\
(7.840)\end{array}$ & $\begin{array}{c}\text { Coef. } \\
-25.46^{* *}\end{array}$ & $\begin{array}{l}\text { Std err. } \\
\quad(9.999)\end{array}$ & $\begin{array}{l}\text { Coef. } \\
.3550^{* *}\end{array}$ & $\begin{array}{r}\text { Std err. } \\
(.0518)\end{array}$ & $\begin{array}{l}\text { Coef. } \\
2.310\end{array}$ & $\begin{array}{r}\text { Std err. } \\
(18.65)\end{array}$ \\
\hline Poly & & & & & & & & & $34.82^{* *}$ & $(15.67)$ \\
\hline WifeNum & & & & & -.3640 & $(7.482)$ & & & & \\
\hline Fem*WifeNum & & & & & -.8677 & $(5.660)$ & & & & \\
\hline Fem*Poly & & & .2073 & $(10.96)$ & & & & & $-50.82^{*}$ & $(29.40)$ \\
\hline Size 1 & $73.14^{* *}$ & $(22.01)$ & $73.13^{* *}$ & $(22.02)$ & $59.84^{* *}$ & $(17.92)$ & -.0179 & $(.0399)$ & $55.87^{* *}$ & (13.95) \\
\hline Size 2 & $21.12^{* *}$ & $(9.380)$ & $21.11^{* *}$ & $(9.464)$ & 13.70 & $(9.216)$ & .0320 & $(.0349)$ & $21.45^{* *}$ & $(7.279)$ \\
\hline Size 3 & 4.033 & $(8.558)$ & 4.028 & $(8.601)$ & -4.709 & $(8.344)$ & .0151 & $(.0330)$ & 5.148 & $(7.070)$ \\
\hline Size 4 & -7.831 & $(7.085)$ & -7.841 & $(7.032)$ & $-14.63^{* *}$ & $(6.894)$ & .0324 & $(.0372)$ & -2.279 & $(7.062)$ \\
\hline Size 6 & -1.251 & $(8.409)$ & -1.263 & $(8.434)$ & -10.94 & $(8.428)$ & $.0577^{*}$ & $(.0341)$ & -5.465 & $(6.916)$ \\
\hline Size 7 & -8.357 & $(9.106)$ & -8.365 & $(9.130)$ & -11.12 & $(7.660)$ & .0373 & $(.0323)$ & -7.316 & $(7.078)$ \\
\hline Size 8 & $-15.61^{*}$ & $(8.313)$ & $-15.62^{*}$ & $(8.298)$ & $-15.16^{* *}$ & $(7.055)$ & .0414 & $(.0326)$ & -10.74 & $(7.196)$ \\
\hline Size 9 & $-20.39 * *$ & $(9.380)$ & $-20.40^{* *}$ & $(9.304)$ & $-21.93^{* *}$ & $(8.795)$ & .0413 & $(.0348)$ & $-19.34^{* *}$ & $(7.820)$ \\
\hline Size 10 & $-20.83^{* *}$ & $(7.968)$ & $-20.84^{* *}$ & $(7.957)$ & $-24.69^{* *}$ & $(7.885)$ & .0463 & $(.0295)$ & $-21.32^{* *}$ & $(7.541)$ \\
\hline Wolof & & & & & & & $.0671^{* *}$ & $(.0154)$ & & \\
\hline Diakhanke & & & & & & & $-.0694^{*}$ & $(.0388)$ & & \\
\hline Fem*Wolof & & & & & & & $.3950^{* *}$ & $(.0613)$ & & \\
\hline Fem+Fem*Poly & & & $-26.33^{* *}$ & $(6.982)$ & & & & & $-48.51^{* *}$ & $(13.43)$ \\
\hline Observations & 12 & & & & & & & & 12 & \\
\hline $\begin{array}{l}\text { Angrist-Pischke } \\
\text { (Stock-Yogo 5\% }\end{array}$ & $\begin{array}{l}\text { test of exc } \\
\text { naximal IV }\end{array}$ & $\begin{array}{l}\text { uded instr } \\
\text { elative bic }\end{array}$ & $\begin{array}{l}\text { iments } \\
\text { s) }\end{array}$ & & & & $\begin{array}{r}\mathrm{F}(2,116 \\
(13\end{array}$ & $\begin{array}{l}=19.07 \\
91)\end{array}$ & & \\
\hline $\begin{array}{l}\text { J-Stat. of overide } \\
\text { (P-value) }\end{array}$ & ntification & striction & & & & & & & $\begin{array}{r}\text { Chi2(1 } \\
\quad(.84\end{array}$ & $\begin{array}{l}=.040 \\
1)\end{array}$ \\
\hline
\end{tabular}


Table 7: Fisrt-stage regression results for Poly - Benin, Burkina Faso and Senegal

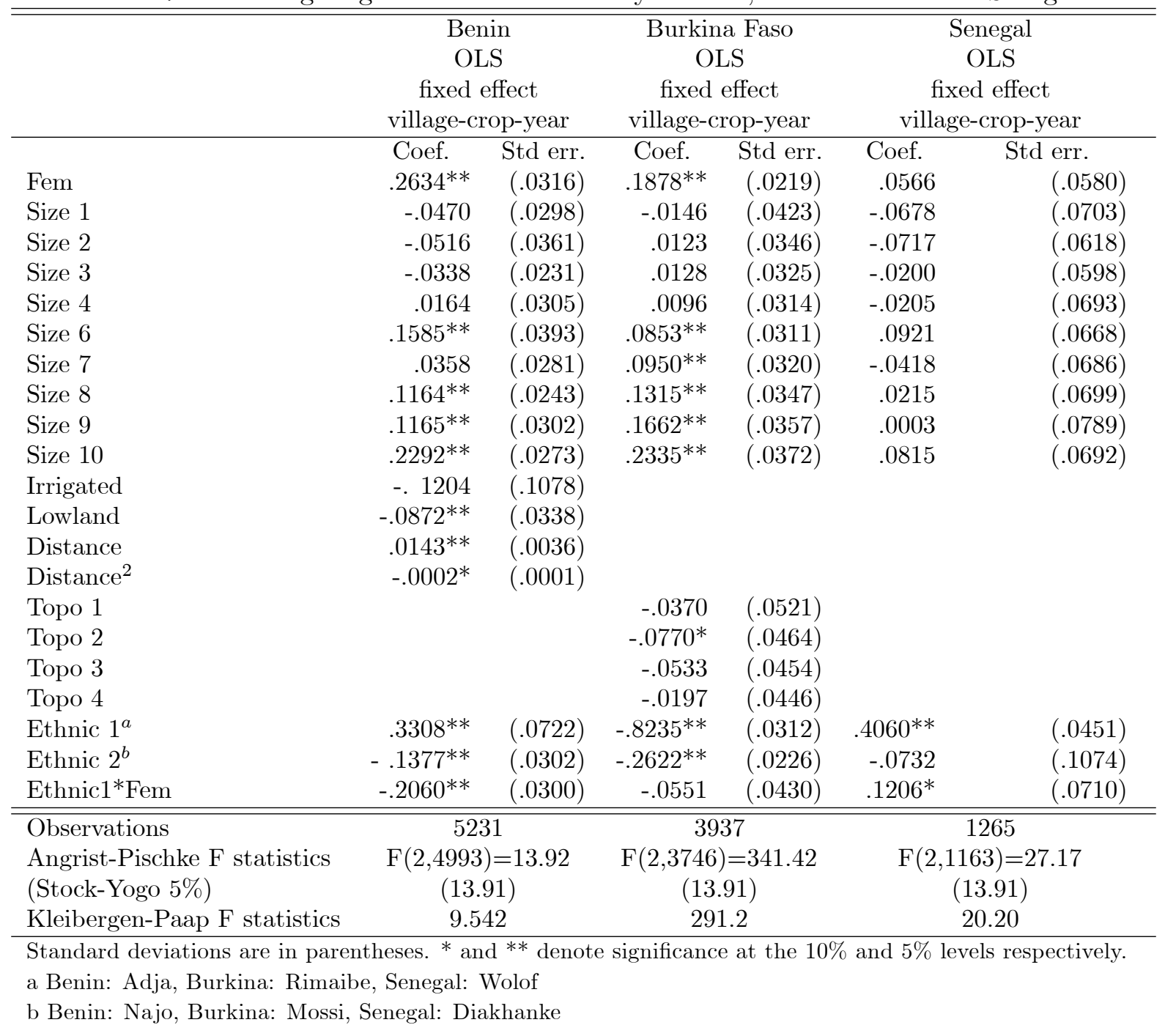


Table 8: More specifications - Benin

\begin{tabular}{|c|c|c|c|c|c|c|c|c|}
\hline & \multicolumn{2}{|c|}{ OLS } & $\begin{array}{r}\mathrm{O} \\
\text { fixed } \\
\text { hous }\end{array}$ & $\begin{array}{l}\text { fixed effect } \\
\text { household }\end{array}$ & \multicolumn{2}{|c|}{$\begin{array}{c}\text { fixed effect } \\
\text { household-year }\end{array}$} & \multicolumn{2}{|c|}{$\begin{array}{c}\text { OLS } \\
\text { fixed effect } \\
\text { household-year-crop }\end{array}$} \\
\hline & Coef. & Std err. & Coef. & Std err. & Coef. & Std err. & Coef. & Std err. \\
\hline \multicolumn{9}{|c|}{ Without controls on plot characteristics } \\
\hline Fem & -69.46 & $(17.37)$ & -5.437 & $(15.09)$ & -5.506 & $(15.28)$ & -15.22 & $(17.15)$ \\
\hline \multicolumn{9}{|c|}{ With controls on plot characteristics } \\
\hline Fem & $92.65^{* *}$ & $(22.37)$ & $-81.68^{* *}$ & $(29.51)$ & $-73.31^{* *}$ & $(29.67)$ & $-40.16^{* *}$ & $(19.38)$ \\
\hline Size 1 & $697.5^{* *}$ & $(112.1)$ & $881.5^{* *}$ & $(165.5)$ & $863.3^{* *}$ & $(163.32)$ & $159.4^{* *}$ & $(51.00)$ \\
\hline Size 2 & $109.5^{* *}$ & $(28.9)$ & $193.7^{* *}$ & $(67.55)$ & $215.6^{* *}$ & $(76.97)$ & $111.1^{* *}$ & (28.96) \\
\hline Size 3 & $34.88 * *$ & $(13.58)$ & $81.48^{* *}$ & $(23.53)$ & $80.64^{* *}$ & $(24.32)$ & $52.4^{* *}$ & (12.66) \\
\hline Size 4 & 20.55 & $(18.88)$ & 41.2 & $(43.40)$ & 39.81 & $(48.2)$ & $37.82^{* *}$ & (17.12) \\
\hline Size 6 & -33.43 & $(21.69)$ & 15.73 & $(42.07)$ & 15.81 & $(43.32)$ & 31.42 & (26.04) \\
\hline Size 7 & -17.66 & (13.05) & 8.290 & $(31.68)$ & 10.46 & $(31.23)$ & 17.73 & (17.23) \\
\hline Size 8 & $-35.09 * *$ & $(10.82)$ & $-96.93^{* *}$ & $(34.71)$ & $-92.05^{* *}$ & $(35.47)$ & 6.669 & (15.16) \\
\hline Size 9 & $-53.83^{* *}$ & $(14.15)$ & -48.03 & $(31.90)$ & -21.46 & $(27.39)$ & 4.538 & $(12.22)$ \\
\hline Size 10 & $-48.84^{* *}$ & $(10.74)$ & $-230.9^{* *}$ & $(56.63)$ & $-225.8^{* *}$ & $(65.59)$ & -17.26 & (13.38) \\
\hline Irrigated & 555.6 & $(481.4)$ & -346.2 & $(228.5)$ & $-373.6^{* *}$ & $(200.3)$ & $-22.18^{* *}$ & $(7.864)$ \\
\hline Lowland & $139.6^{*}$ & $(72.91)$ & -85.47 & (148.8) & -182.9 & $(121.2)$ & -34.85 & (49.35) \\
\hline Distance & $16.13^{* *}$ & $(6.683)$ & $16.38^{*}$ & $(9.696)$ & $15.81^{*}$ & $(8.277)$ & 2.703 & (2.531) \\
\hline Distance $^{2}$ & $-.402 * *$ & $(.1957)$ & -.3970 & $(.2679$ & $-.4055^{*}$ & $(.2454)$ & -.1700 & $(.1143)$ \\
\hline Observ. & \multicolumn{2}{|c|}{5231} & \multicolumn{2}{|c|}{5231} & \multicolumn{2}{|c|}{5231} & \multicolumn{2}{|c|}{5231} \\
\hline
\end{tabular}

Standard deviations are in parentheses. ${ }^{*}$ and ${ }^{* *}$ denote significance at the $10 \%$ and $5 \%$ levels respectively. 
Table 9: More specifications - Burkina

\begin{tabular}{|c|c|c|c|c|c|c|c|c|}
\hline & \multicolumn{2}{|c|}{ OLS } & \multicolumn{2}{|c|}{$\begin{array}{l}\text { OLS } \\
\text { fixed effect } \\
\text { household }\end{array}$} & \multicolumn{2}{|c|}{$\begin{array}{c}\text { OLS } \\
\text { fixed effect } \\
\text { household-year }\end{array}$} & \multicolumn{2}{|c|}{$\begin{array}{c}\text { OLS } \\
\text { fixed effect } \\
\text { household-year-crop }\end{array}$} \\
\hline & Coef. & Std err. & Coef. & Std err. & Coef. & Std err. & Coef. & Std err. \\
\hline \multicolumn{9}{|c|}{ Without controls on plot characteristics } \\
\hline Fem & $18.00^{* *}$ & $(5.557)$ & $21.16^{* *}$ & $(7.736)$ & $22.33^{* *}$ & $(7.576)$ & -1.744 & $(4.322)$ \\
\hline \multicolumn{9}{|c|}{ With controls on plot characteristics } \\
\hline Fem & $-27.34^{* *}$ & $(7.093)$ & $-37.58^{* *}$ & $(8.135)$ & $-37.78^{* *}$ & $(9.398)$ & $-31.49^{* *}$ & $(6.627)$ \\
\hline Size 1 & $162.2^{* *}$ & $(17.37)$ & $167.9^{* *}$ & $(17.35)$ & $170.5^{* *}$ & $(17.18)$ & $149.3^{* *}$ & $(41.80)$ \\
\hline Size 2 & $58.16^{* *}$ & $(11.41)$ & $61.91^{* *}$ & $(12.02)$ & $67.52^{* *}$ & (11.98) & $76.91^{* *}$ & (16.65) \\
\hline Size 3 & $49.34^{* *}$ & $(9.772)$ & $49.15^{* *}$ & $(9.295)$ & $53.31^{* *}$ & $(10.24)$ & $69.40^{* *}$ & (12.88) \\
\hline Size 4 & $25.41^{* *}$ & $(10.80)$ & $24.99^{* *}$ & (10.57) & $27.99 * *$ & $(10.42)$ & $34.17^{* *}$ & (13.35) \\
\hline Size 6 & $-15.98^{* *}$ & $(6.447)$ & $-23.03^{* *}$ & $(6.870)$ & $-17.48^{* *}$ & $(6.272)$ & -0.483 & $(7.809)$ \\
\hline Size 7 & $-25.99 * *$ & $(6.075)$ & $-29.73^{* *}$ & $(6.495)$ & $-24.94^{* *}$ & $(6.714)$ & -13.47 & (8.379) \\
\hline Size 8 & $-31.37^{* *}$ & $(6.296)$ & $-33.63^{* *}$ & $(6.881)$ & $-31.85^{* *}$ & $(7.251)$ & $-16.88^{* *}$ & (7.488) \\
\hline Size 9 & $-41.51^{* *}$ & $(6.453)$ & $-49.64^{* *}$ & $(7.076)$ & $-44.43^{* *}$ & $(7.837)$ & $-28.83^{* *}$ & $(7.670)$ \\
\hline Size 10 & $-40.11^{* *}$ & $(7.135)$ & $-49.40^{* *}$ & $(7.384)$ & $-46.82^{* *}$ & $(8.382)$ & $-33.98^{* *}$ & $(7.696)$ \\
\hline Topo 1 & $-104.4^{* *}$ & (19.65) & $-97.29 * *$ & $(23.88)$ & $-112.6^{* *}$ & $(25.17)$ & $-37.77^{*}$ & $(22.29)$ \\
\hline Tоро 2 & $-102.1^{* *}$ & (17.68) & $-103.2^{* *}$ & $(21.95)$ & $-109.3^{* *}$ & $(23.08)$ & -23.94 & (23.01) \\
\hline Topo 3 & $-96.63^{* *}$ & $(18.00)$ & $-91.35^{* *}$ & $(20.28)$ & $-90.1^{* *}$ & $(22.07)$ & -20.41 & (22.69) \\
\hline Topo 4 & $-76.61^{* *}$ & $(19.36)$ & $-73.61^{* *}$ & $(21.68)$ & $-70.99 * *$ & $(22.17)$ & -14.20 & $(27.64)$ \\
\hline Observ. & \multicolumn{2}{|c|}{3956} & \multicolumn{2}{|c|}{3956} & \multicolumn{2}{|c|}{3956} & \multicolumn{2}{|c|}{3956} \\
\hline
\end{tabular}

Standard deviations are in parentheses. ${ }^{*}$ and ${ }^{* *}$ denote significance at the $10 \%$ and $5 \%$ levels respectively. 
Table 10: More specifications - Senegal

\begin{tabular}{|c|c|c|c|c|c|c|c|c|}
\hline & \multicolumn{2}{|c|}{ OLS } & \multicolumn{2}{|c|}{$\begin{array}{l}\text { OLS } \\
\text { fixed effect } \\
\text { household }\end{array}$} & \multicolumn{2}{|c|}{$\begin{array}{c}\text { OLS } \\
\text { fixed effect } \\
\text { household-year }\end{array}$} & \multicolumn{2}{|c|}{$\begin{array}{c}\text { OLS } \\
\text { fixed effect } \\
\text { household-year-crop }\end{array}$} \\
\hline & Coef. & Std err. & Coef. & Std err. & Coef. & Std err. & Coef. & Std err. \\
\hline \multicolumn{9}{|c|}{ Without controls on plot characteristics } \\
\hline Fem & 2.305 & $(4.521)$ & -3.053 & $(6.756)$ & -5.369 & $(6.657)$ & -19.05 & $(6.108)$ \\
\hline \multicolumn{9}{|c|}{ With controls on plot characteristics } \\
\hline Fem & -3.092 & $(4.893)$ & $-15.71^{* *}$ & $(7.361)$ & $-19.12^{* *}$ & $(7.285)$ & $-33.52^{* *}$ & $(7.485)$ \\
\hline Size 1 & $37.11^{* *}$ & $(13.42)$ & $41.95^{* *}$ & $(14.10)$ & $43.37^{* *}$ & $(14.96)$ & $73.14^{* *}$ & $(22.01)$ \\
\hline Size 2 & 10.95 & $(7.328)$ & 9.124 & $(9.096)$ & 6.500 & $(11.00)$ & $21.12^{* *}$ & (9.377) \\
\hline Size 3 & 11.02 & $(7.372)$ & -4.795 & $(9.713)$ & -8.370 & $(11.36)$ & 4.033 & (8.558) \\
\hline Size 4 & 1.782 & $(7.452)$ & -14.22 & $(7.992)$ & -13.96 & $(8.896)$ & -7.831 & (7.085) \\
\hline Size 6 & .5447 & $(6.845)$ & -10.58 & $(9.909)$ & -12.67 & $(12.36)$ & -1.251 & (8.409) \\
\hline Size 7 & -9.515 & $(6.954)$ & $-17.99^{* *}$ & $(8.226)$ & $-19.53^{* *}$ & $(9.844)$ & -8.357 & (9.106) \\
\hline Size 8 & 4.213 & $(7.090)$ & $-15.95^{*}$ & $(8.691)$ & $-21.27^{* *}$ & (9.697) & $-15.61^{*}$ & (8.313) \\
\hline Size 9 & -7.219 & $(7.057)$ & $-22.48^{* *}$ & $(9.267)$ & $-26.60 * *$ & (10.98) & $-20.39^{* *}$ & $(9.380)$ \\
\hline Size 10 & -7.975 & $(6.935)$ & $-28.51^{* *}$ & $(8.796)$ & $-31.73^{* *}$ & $(9.801)$ & $-20.83^{* *}$ & $(7.968)$ \\
\hline Observ. & \multicolumn{2}{|c|}{1258} & \multicolumn{2}{|c|}{1258} & \multicolumn{2}{|c|}{1258} & \multicolumn{2}{|c|}{1258} \\
\hline
\end{tabular}

Standard deviations are in parentheses. ${ }^{*}$ and ${ }^{* *}$ denote significance at the $10 \%$ and $5 \%$ levels respectively. 